\title{
Eğitim Yapılarında Aydınlatma Türü ve Kullanımı Önerileri: Kocaeli Üniversitesi Mimarlık Fakültesi Binası
}

\author{
Büşra ONAK ${ }^{1 \star}$, Nihan YILDIRAN ${ }^{1}$
}

Öz

Eğitim yapılarında aydınlatma, dersliklerde gün boyu devam eden eğitim süreci nedeniyle görsel konfor ve enerji tüketimi açısında önemli bir konudur. Bu etkenler düşünüldüğünde gün ışığı aydınlatma için en iyi çözümdür. Ancak yetersiz kaldığı durumlarda doğru tasarlanmış yapay aydınlatma ile desteklenmelidir.

Doğal aydınlatma, güneşin günlük ve mevsimsel hareketlerine bağlı olarak, sabit aydınlık düzeyi sağlamaz. Bu değişkenlik sebebiyle dersliklerde düzgün dağılımlı aydınlatma düzeyi oluşturmak ve enerji tasarrufu sağlamak üzere tasarlanacak aydınlatma sistemlerinin türü, miktarı, gücü, konumu önemlidir. Bu bağlamda Mimarlıkta Enerji Etkin Tasarım yüksek lisans dersi kapsamında gerçekleştirilen çalışmada Kocaeli Üniversitesi Mimarlık Fakültesi'nde belirlenen atölyelerde mevcut aydınlık seviyesi ve dağılımı tespit edilmiş, sonuçlar standartlar ile karşılaştırılıp değerlendirilmiştir. Bu değerlendirmeye göre görsel konfor koşullarını artırmak, enerji tüketimini azaltmak üzere uygun aydınlatma sistemlerinin seçimi ve kullanım biçimlerinin belirlenmesine yönelik çalışma gerçekleştirilmiştir.

Belirlenen atölyelerden en riskli verilere sahip olan Atölye A, DIALux Evo programında modellenmiştir. Farklı aydınlatma gücü ve türünde elemanlarının kullanıldığı öneriler getirilmiştir. Bu öneriler, enerji tüketim miktarı ve görsel konfor koşulları üzerinden değerlendirilmiş, atölye için en uygun aydınlatma planı önerilmiştir.

Anahtar kelimeler: Aydınlatma Tasarımı, Eğitim Yapıları, Yapay Aydınlatma, Enerji Tasarrufu, Görsel Konfor

\section{Lighting Type and Usage Suggestions in Educational Buildings: Kocaeli University Faculty of Architecture Building}

\begin{abstract}
Lighting in educational buildings is an important issue in terms of visual comfort and energy consumption due to the education process that continues throughout the day in classrooms. Considering these factors, daylight is the best solution for lighting. However, in cases where it is insufficient, it should be supported with properly designed artificial lighting.
\end{abstract}

Daylighting does not provide a constant level of illumination, depending on the daily and seasonal movements of the sun. Due to this variability, the type, amount, power and location of the lighting systems, designed to create a uniform level of illumination and provide energy conservation are important issues in classrooms. In this context, in this study carried out within the scope of "Energy Efficient Design in Architecture" lecture of graduate, the level and distribution of illumination in the selected studios at Kocaeli University Faculty of Architecture and the results were compared and evaluated with the standards. According to this assessment, a study was conducted to select sui-

\footnotetext{
${ }^{1}$ Mimar, Kocaeli Üniversitesi, FBE, Mimarlık Anabilim Dalı,

* İlgili yazar/Corresponding author: busraonak96@gmail.com

Gönderim Tarihi / Received Date: 19.03.2020

Kabul Tarihi / Accepted Date: 29.11.2020
} 
table lighting systems and to determine their control systems in order to increase the visual comfort conditions and reduce energy consumption.

Studio A, which has the most risky condition in terms of lighting among the selected studios, was modeled on the DIALux Evo program. Simulations were conducted in which lighting systems with different lighting power and type were defined. All these parameters performances were evaluated due to their effect to energy consumption amounts and visual comfort conditions

Keywords: Illumination Design, Educational Buildings, Artificial Lighting, Energy Conservation, Visual Comfort

\section{GiRiş}

Günümüzde enerji tüketimi küresel bir problemdir ve bu tüketimin büyük çoğunluğu yapı kaynaklıdır. "Türkiye'de, 2017 yılında toplam enerji tüketiminin dağılımına bakıldığında, en yüksek tüketimin \%24,8 ile mesken ve hizmetler ve \%24,4 ile sanayi sektöründe gerçekleştiği görülmektedir" (URL 1). Bu sebeple binaların tasarım aşamasından yapım aşamasına kadar olan süreç, tüketimi azaltma ve konforu arttırma doğrultusunda düşünülmelidir. 2009 yılındaki faaliyet raporlarına göre binalardaki toplam enerji tüketiminin \%20'si aydınlatma amaçlıdır (Sümengen ve Yener, 2015). Bundan dolayı enerji verimliliği açısından öncelikli düşünülmesi gereken konulardan biri aydınlatmadır. Bunun yanı sıra aydınlatmanın insan üzerinde fizyolojik ve psikolojik etkileri vardır (Heschong ve diğ., 2002). İyi bir aydınlatma tasarımı gözün görme yeteneğini arttırır, kaza olasılığını azaltır, yapılan işin verimliliğini yükseltir, güvenli bir ortam sağlar.

Aydınlatma ihtiyacından kaynaklanan enerji tüketiminin düşürülmesi ve konfor koşullarının sağlanması için mekânda aydınlatma öncelikli olarak doğal aydınlatma ile sağlanmalıdır. Yetersiz ve eksik kaldığı durumlarda ise yapay aydınlatma ile desteklenmelidir. Yapay aydınlatma tasarımı mekânın işlevine ve dış hava koşullarına göre planlanmalıdır.

Aydınlatma tasarımı konusu çok yönlü bir araştırma alanıdır ve literatür araştırması sırasında birçok çalışma incelenmiştir. Yıldız (2018), mevcut örnek üzerinden dersliklerdeki ortalama gün ışığı performansını incelemiştir. Bu çalışmada görsel konforun sağlanması için pencere büyüklükleri, yönelim ve engeller gibi birçok parametrenin bir arada değerlendirilmesi gerektiği görülmektedir. Salata ve diğ. (2016), mevcut örneği DIALux Evo programında modellemiş, doğal ve yapay aydınlatmanın birlikte kullanılma durumunu incelemişlerdir. Çalışmada görsel konfor ve enerji tasarrufu için en uygun yöntemin bütünleşik aydınlatma sistemi olduğu ve bu sistemin de önceden güne ve saate göre belirlenmiş kontrol sistemleriyle çalışması gerektiğine sonucuna ulaşmışlardır. Cao ve diğ. (2020), mevcut ofis yapısındaki aydınlatma durumunu ölçmüş, sonrasında gün ışığını Rhino programı, yapay ışığı da DIALux Evo programı ile simüle etmişlerdir. Işık kaynağının parametrelerini ve konumunu değiştirerek optimum aydınlık düzeyi ve enerji tasarrufu sağlamışlardır. Bircan ve Yener'in (2019) çalışmasında, "Eğitim Yapıları Asgari Tasarım Standartları Kılavuzu” çerçevesinde DIALux programında pencere boyutları farklı olacak şekilde iki senaryo oluşturdukları görülmektedir. Dersliklerdeki günışığı performansını görmek amacıyla yıl içindeki aydınlık seviyelerini "TS EN 17037" göre değerlendirmişlerdir. Böylece tasarımlarda günışığının gün içindeki ve yıl içindeki değişkenliğinin göz önüne alınması gerektiği görülmektedir. Erlalelitepe ve diğ. (2011), mevcut yapılar için doğal aydınlatma sistemleri, tasarım elemanları ve aydınlatma performansını değerlendirme yöntemlerinden bahsetmektedirler. Örnek bir yapı üzerinden ölçüm yapmışlar ve bulguları çizelgeler ve çizimler aracılığıyla sunmuşlardır. 
Bu makalede mekânda düzgün bir aydınlık düzeyi oluşturmak ve enerji tasarrufu amacıyla yapay aydınlatma sistem ve kullanım önerileri ile sağlanabilecek kazanımları belirlemeye yönelik bir çalışma gerçekleştirilmiştir. Yapılan literatür çalışmasında bütünleşik aydınlatma sisteminin optimum koşulları sağlayan çözüm olduğu belirtilmiştir. Bunun yanı sıra incelemelerde yapay aydınlatma konusunda mekândaki ortalama aydınlık düzeyi üzerinden iyileştirme yapıldığı görülmüştür. Bu çalışmada homojen bir aydınlık seviyesi sağlanması amacıyla mekân bölgelere ayrılmış, bölge odaklı ve bütünleşik aydınlatma sisteminin kullanıldığı bir iyileştirme yapılmıştır. Bunun yanında doğal ışığın gün içindeki durumu göz önüne alınarak bir armatürlerin anahtar planı hazırlanmıştır.

Aydınlatma konusu tek başlık altında incelemek için geniş bir konudur. Her işlevsel yapının intiyaç duyduğu aydınlık düzeyi, ışık rengi farklıdır. Eğitim ve üretkenlik gibi görsel algılamanın önemli olduğu ve farklı kullanıcılara (eğitmen, öğrenci, personel) hizmet veren eğitim yapılarında aydınlatma alt başlık halinde incelenmelidir. Aydınlatma tasarımı, kullanıcıların iyi bir eğitim alabilmesi için süreci olumsuz etkilememelidir. Bu sebeple belirlenen eğitim yapısındaki dersliklerde ölçüm ve analizler sonucu kullanım amacını destekler biçimde hem görsel konfor hem de enerji tasarrufu açısından en uygun olan aydınlatma sistemi ve kullanımı DIALux Evo programında yapılan simülasyon önerileri ile belirlenmiştir.

\section{EĞiTIM YAPILARINDA AYDINLATMA}

Eğitim yapıları ülke nüfusunun yaklaşık \%20'sinin etkin olarak kullandığı yapılardır ve işlevi nedeniyle gelecek nesillerin yetişmesinde önemi büyüktür (Çelik ve Ünver, 2019). Eğitim yapılarında, öğrenim sürecini etkileyen birçok faktör vardır, bunlardan biri aydınlatma konusudur. Aydınlatma fiziksel çevreyi etkilediği gibi insanın fizyolojik ve psikolojik sağlığını etkiler (Memiş ve Ekren, 2019). Dersliklerde görsel konfor koşullarının sağlanması, bu eylemin zorlanmadan, yorulmadan ve verimli biçimde gerçekleştirilmesi açısından özenle üzerinde durulması gereken bir konudur (Yağmur ve Sözen, 2016).

İşleve uygun tasarlanan aydınlatma, kullanıcılar için iyi bir görsel konfor sunarken aynı zamanda enerji tüketimini azaltır. Bu çalışmada eğitim yapıları kapsamında Kocaeli Üniversitesi Mimarlık ve Tasarım Fakültesi binası incelenmiştir. Grafik-1'de görüldüğü üzere üniversite yapılarındaki elektrik tüketiminin \%25'ini aydınlatma giderleri oluşturur.

Üniversite yapılarının aktif kullanım zaman aralığı, aydınlatma için gün ışığından faydalanmaya elverişlidir. Doğal aydınlatma, enerji tasarrufu sağlarken aynı zamanda öğrencilerin sağlığını olumlu etkiler ve daha iç açıcı bir ortam yaratır (Michael ve Heracleous, 2016). Bu sebeple dersliklerdeki aydınlatma doğal aydınlatma ile sağlanmalı, yetersiz kaldığı durumlar için uygun bir yapay aydınlatma tasarımı yapıımalıdır. Doğal aydınlatmanın faydaları düşünülmeden planlanan yapılarda aydınlık gereksinimi büyük ölçüde yapay aydınlatma ile karşılanmaktadır. Bu durum optimum görsel konfor koşullarını sağlasa da enerjiyi verimsiz kullanmaya sebep olur. 


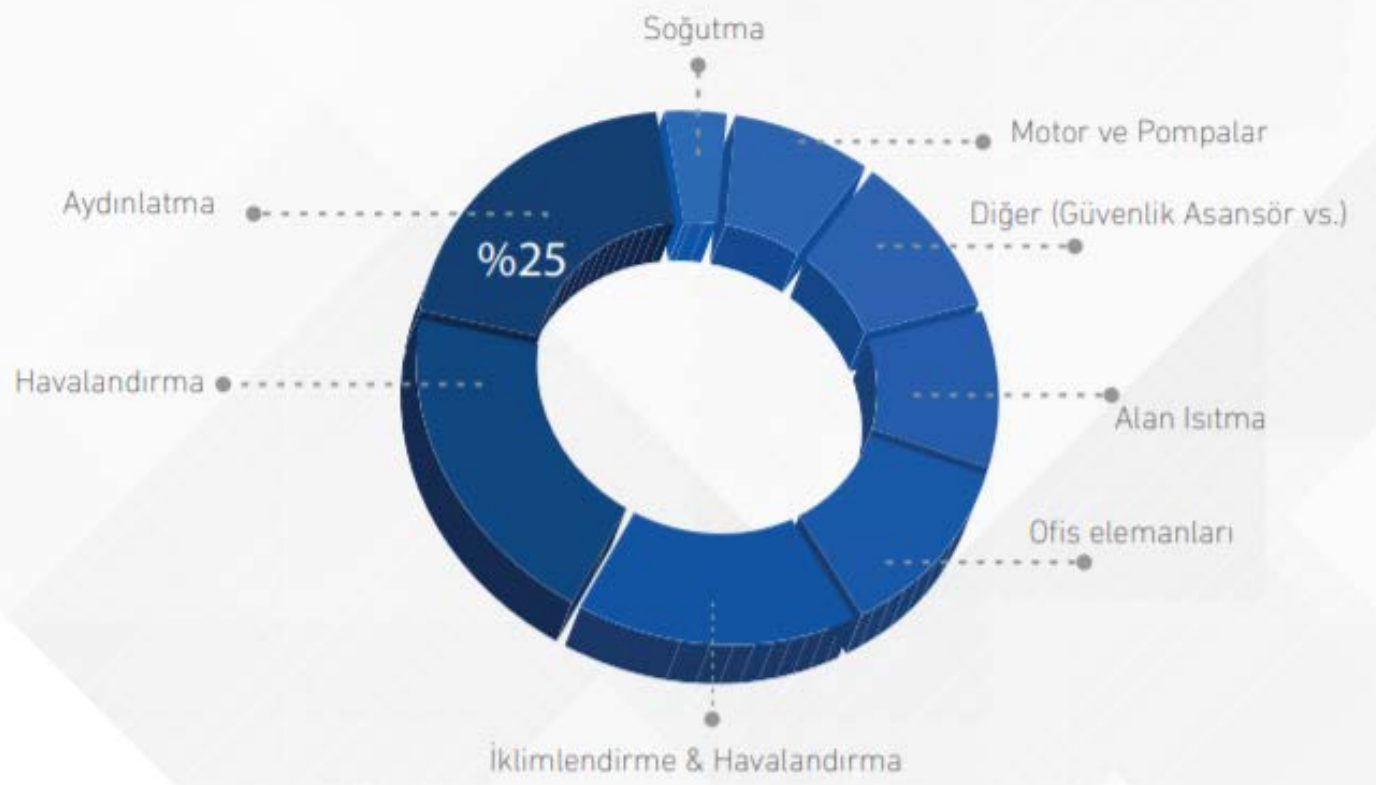

Grafik 1: Üniversite binalarında yıllık elektrik enerjisi tüketiminin dağıımı (URL 2)

\section{MEKÂN VE METOT}

Bu çalışmada, Kocaeli Üniversitesi Anıtpark Yerleşkesinde bulunan Mimarlık ve Tasarım Fakültesi binasındaki dersliklerin aydınlık düzeyleri incelenmiştir. Fakültede Mimarlık ve İç Mimarlık programları bulunmaktadır. Binada, atölyeler, seminer odaları, bilgisayar laboratuvarı, maket atölyesi, akademik ve idari personel odaları ve konferans salonu mevcuttur.

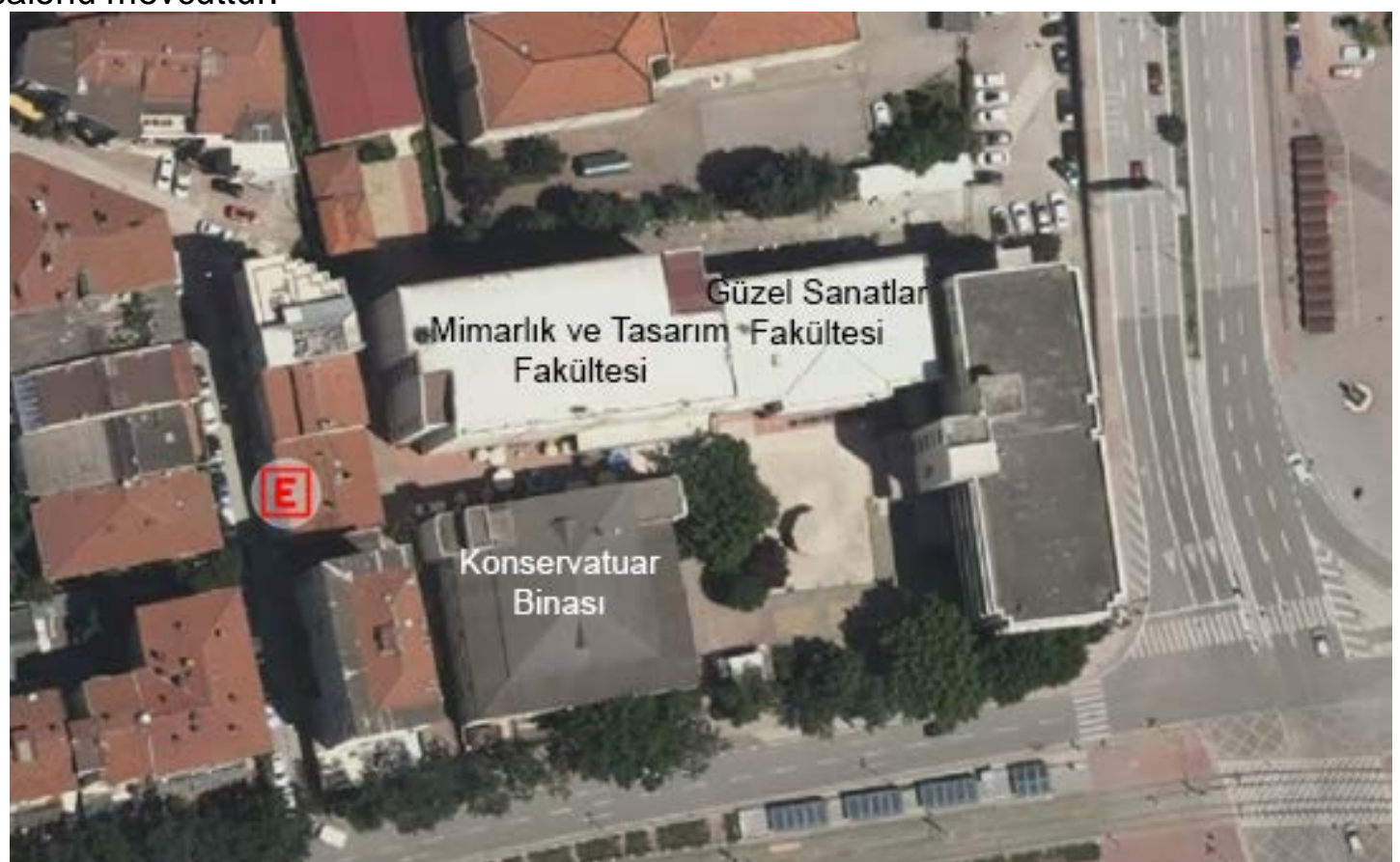

Resim 1: Mimarlık ve Tasarım Fakültesi (URL 3)

Resim 1'de görüldüğü üzere fakülte binasının güneyinde yer alan Konservatuar binası ve batı yönünde bulunan konut bloğu haricinde engel teşkil edecek bir yapı veya eleman bulunmamaktadır. 

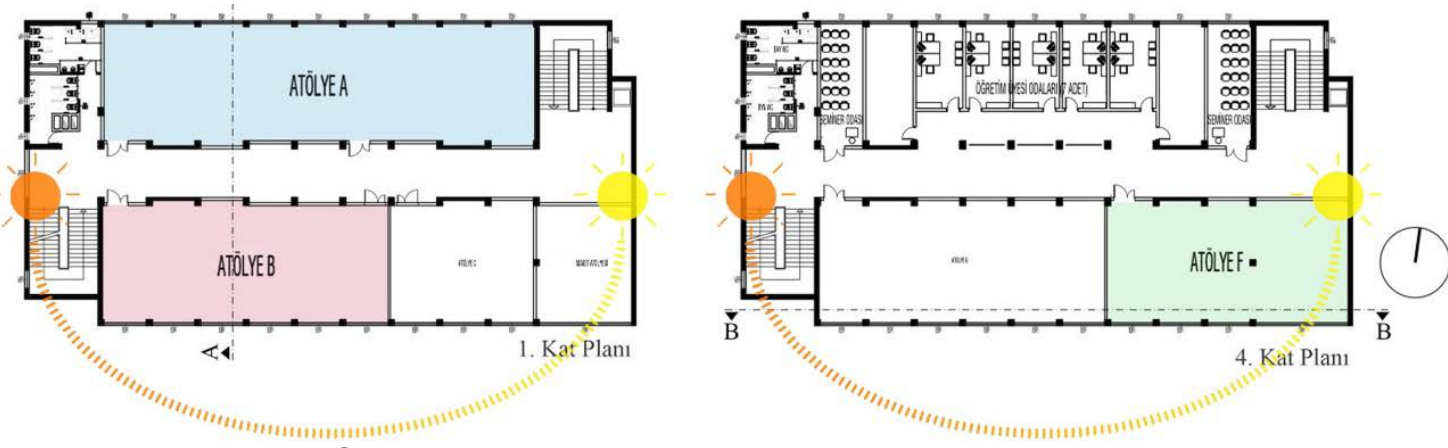

Şekil 1: Kat Planları ve ölçülen atölyelerin konumu

Çalışmada Atölye A, Atölye B ve Atölye F'de ölçümler yapılmıştır. İncelenecek olan atölyeler tek cepheden doğal ışık almaktadır ve yönelimleri ise kuzeye ve güneye doğrudur (Şekil 1). Atölyelerin belirlenmesinde iki kriter göz önünde bulundurulmuştur: ölçüm yapılan günlerde fakülte ders döneminde olduğu için mevcut ders programı, atölyelerin bulunduğu yön ve katlardır. Aynı yöne bakan fakat farklı katlarda konumlanan ve aynı katta fakat farklı yöne bakan atölyeler seçilmiştir (Şekil 2).
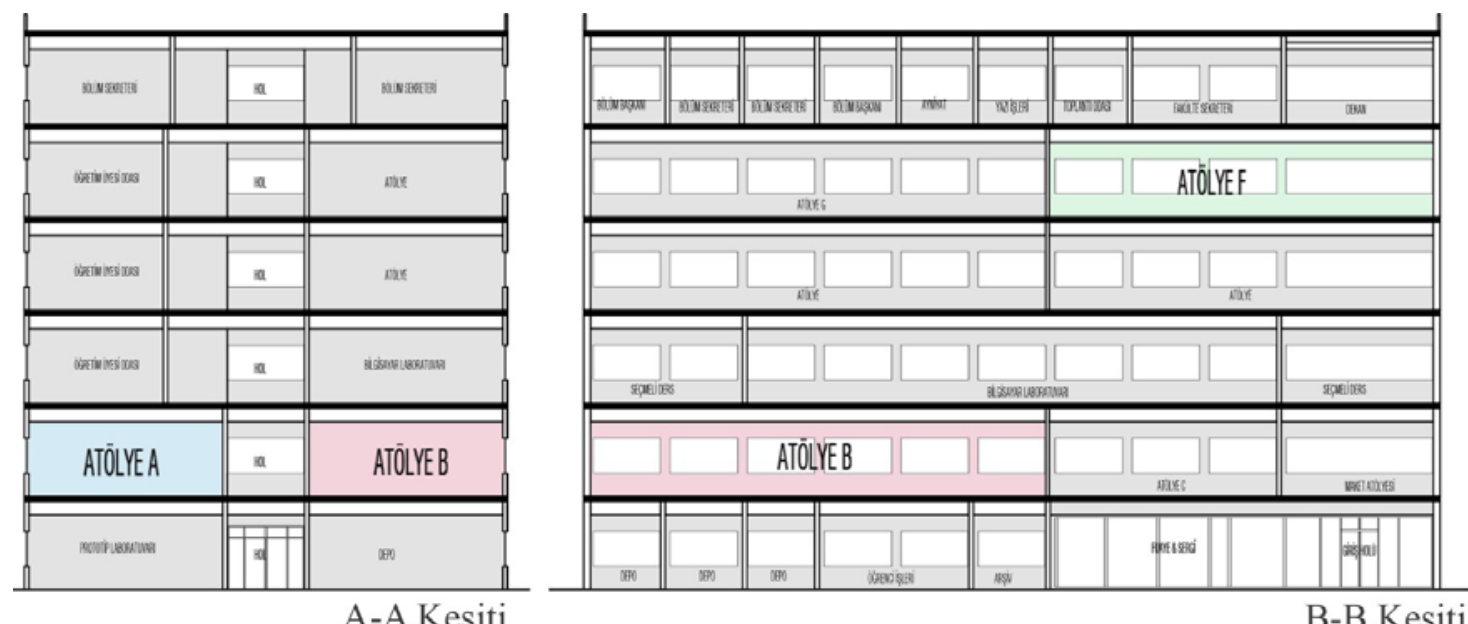

Şekil 2: Atölye A ve Atölye B (Aynı katta farklı yöne bakan atölyeler.)- Atölye B ve Atölye F (Farklı katlardaki aynı yöne bakan atölyeler)

Ölçümün yapılacağı günlerin seçiminde belirleyici kriter ise farklı hava koşullarının etkisini görmektir. Bu sebeple güneşli hava koşullarının olduğu 10.12.2019 Salı günü ve bulutlu hava koşullarının olduğu 23.12.2019 Pazartesi günü seçilmiştir. Ölçüm saati için atölyelerdeki sabah derslerinin başlangıç saati (10.00-11.00) ve derslerin bitiş saati (16.00-17.00) olan zaman aralıkları belirlenmiştir.

Dersliklerdeki ölçüm noktalarının belirlenmesinde oda indeksi formülü kullanılmıştır. Atölye A'da 12 noktada, Atölye B'de ve Atölye F'de ise 9 noktada çalışma düzlemi esas alınarak $(0.70 \mathrm{~m})$ ölçüm yapılmıştır. İç ölçümler yapılırken tüm perdeler açılmış vaziyettedir ve mevcutta herhangi bir güneş kırıcı ya da güneş rafı bulunmamaktadır. Atölyelerde doğal aydınlatma ve doğal aydınlatmayla birlikte yapay aydınlatmanın açık olduğu koşullarda ölçümler gerçekleştirilmiştir. Atölyelerdeki mevcut aydınlatma elemanı, beyaz ışık veren, $60 \times 60 \mathrm{~cm}$ boyutlarında sıva üstü çift parabolik floresan $(4 \times 800 \mathrm{Im})$ armatürdür. Eş zamanlı olarak dış ortam aydınlık düzeyi kuzey ve güney yönde ölçülmüştür. Ölçümler, Extech EA30 aydınlık düzeyi ölçüm cihazı (Ölçüm aralığı: 0400000lux, Doğruluk: \pm 3 lux ya da $\pm 3 \%$ ) ile yapılmıştır. 
Tablo 1: TS EN 12464-1:2013'e göre eğitim binalarındaki aydınlık düzeyi değerleri

\begin{tabular}{|l|l|l|l|}
\hline Ref. no & İç kısım, iş veya Faaliyet tipi & $\begin{array}{l}\text { Aydınlık düzeyi } \\
\left.\text { değeri ( } \mathbf{E}_{\min }\right)\end{array}$ & $\begin{array}{l}\text { Aydınlatmanın } \\
\text {.düzgünlüğü (U) }\end{array}$ \\
\hline 5.36 .1 & Sınıflar, özel ders odaları & 300 lux & 0,60 \\
\hline 5.36 .9 & Uygulama Odaları ve Laboratuvarlar & 500 lux & 0,60 \\
\hline
\end{tabular}

Literatür araştırması sonucu, dersliklerdeki görsel konfor ve aydınlık düzeyi oranını belirleyen birçok standart (CIBSE, IESNA, TS EN 12464-1:2013) olduğu görülmüştür (Erlalelitepe ve diğ., 2011). Bu çalışmada veri altı̆̆ı olarak kullanılan TS EN 124641:2013 standardına göre çalışma düzleminde istenilen minimum aydınlık düzeyi, dersliklerde 300 lux, uygulama derslikleri için ise 500 lux'tür. İki işlev için istenen düzgünlük $\left(E_{\min } / E_{o r t}\right)$ minimum 0.6 olarak belirtilmektedir (Tablo 1).

Tablo 2: Atölye A, Atölye B ve Atölye F

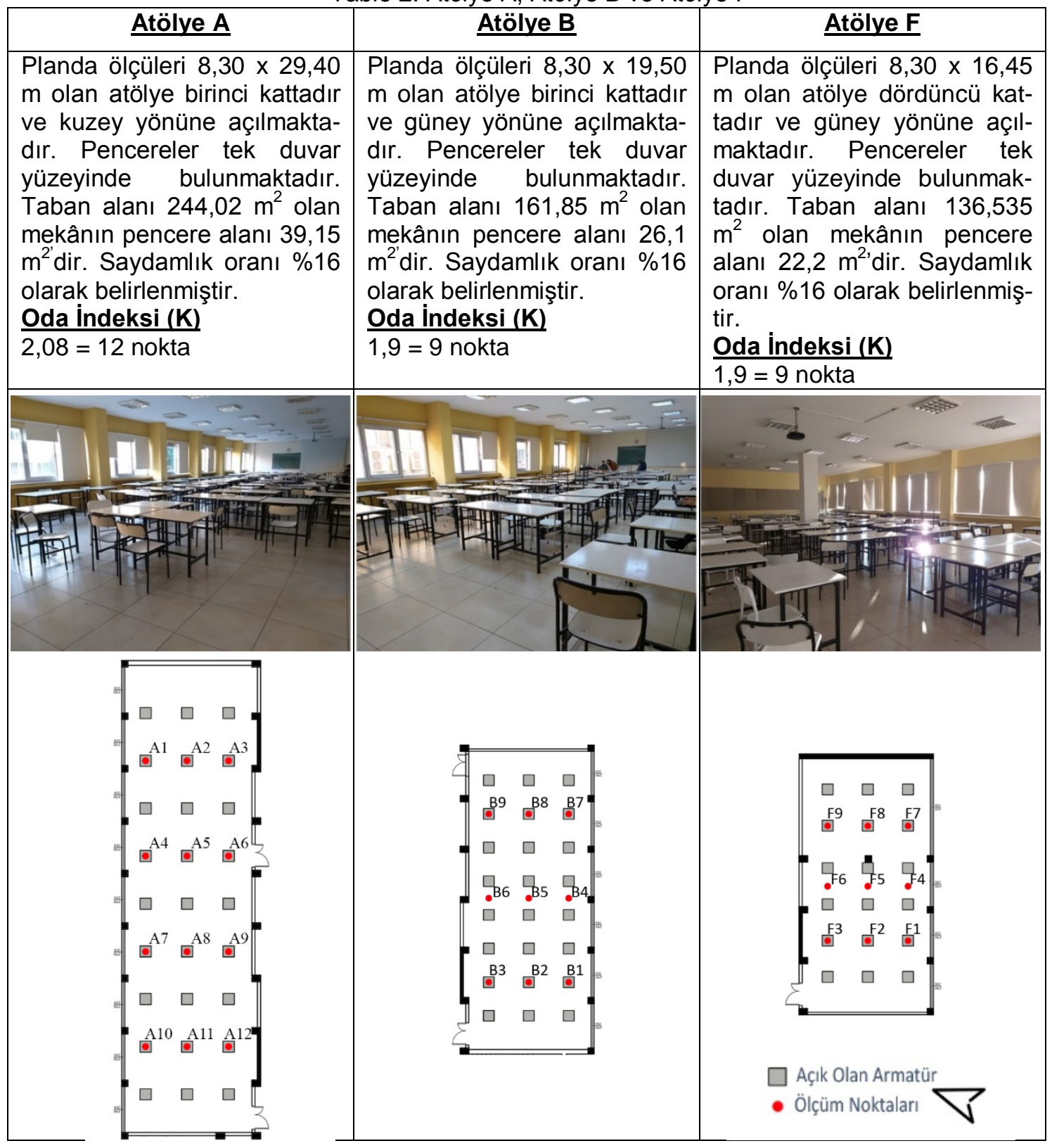




\section{MEVCUT DURUM ANALIZi}

Atölyelerde bulutlu ve güneşli hava koşulları olmak üzere saat $10.00-11.00$ ve 16.00 17.00 zaman aralıklarında ölçüm yapılmıştır. Buna ek olarak eş zamanlı olarak kuzey ve güney yönde dış ortamda aydınlık düzeyi ölçümü yapıımıştır. Yapılan ölçümlerde bulutlu havada, güneşli havaya göre pencere kenarında ve dış ortam ölçümlerinde daha yüksek değerler elde edilmiştir. Bunun sebebi ise, güneşi örtmeyen bulutlu havada gelen toplam ışınımın, bulut varlığı sebebiyle yaygın ışınımın çoğalması ile güneşli havaya oranla artmasıdır (Topçu, 1988, s. 32).

\subsection{Atölyelerin Ölçüm Verilerinin Değerlendirilmesi}

Ölçüm sonuçları değerlendirmesi için TS EN 12464-1:2013 standardındaki min değerler dikkate alınmıştır. Aydınlık düzeyi için min. değer 300 lux, düzgünlük değeri ise min. 0.6 olarak belirtilmiştir. Atölye $A$ için dış ortam ölçümleri, güneşli havada saat 10.00 -

11.00 'da 2.55 Klux, saat 16.00-17.00'da 1.94 Klux; bulutlu havada saat 10.00-11.00'da 2.3 Klux, 16.00-17.00'da 3.51 Klux'tür.

Tablo 3: Atölye A- Doğal Aydınlatma Ölçüm Verileri

\begin{tabular}{|l|l|l|l|l|}
\hline Atölye A- Doğal Aydınlatma Ölçümleri & $\mathbf{E}_{\min }$ & $\mathbf{E}_{\text {ort }}$ & $\mathbf{E}_{\max }$ & $\begin{array}{l}\text { Düzgünlük } \\
\text { ( } \mathbf{E}_{\min } / \mathbf{E}_{\text {ort }} \text { ) }\end{array}$ \\
\hline Güneşli Hava Saat:10.00-11.00 ölçümleri & 39,6 lux & 291,5 lux & 664,7 lux & 0,13 \\
\hline Bulutlu Hava Saat:10.00-11.00 ölçümleri & 35 lux & 299,6 lux & 949 lux & 0,11 \\
\hline Güneşli Hava Saat:16.00-17.00 ölçümleri & 30 lux & 202,6 lux & 516,1 lux & 0,14 \\
\hline Bulutlu Hava Saat:16.00-17.00 ölçümleri & 53 lux & 355,6 lux & 1082 lux & 0,14 \\
\hline
\end{tabular}

Tablo 4: Atölye A- Yapay ve Doğal Aydınlatma Ölçüm Verileri

\begin{tabular}{|l|l|l|l|l|}
\hline Atölye A- Yapay Aydınlatma Ölçümleri & $\mathbf{E}_{\min }$ & $\mathbf{E}_{\text {ort }}$ & $\mathbf{E}_{\max }$ & $\begin{array}{l}\text { Düzgünlük } \\
\text { ( } \mathbf{E}_{\min } / \mathbf{E}_{\text {ort }} \text { ) }\end{array}$ \\
\hline Güneşli Hava Saat:10.00-11.00 ölçümleri & 291.6 lux & 463,8 lux & 723.1 lux & 0,62 \\
\hline Bulutlu Hava Saat:10.00-11.00 ölçümleri & 298 lux & 570,6 lux & 967 lux & 0,52 \\
\hline Güneşli Hava Saat:16.00-17.00 ölçümleri & 298 lux & 531 lux & 791.5 lux & 0,56 \\
\hline Bulutlu Hava Saat:16.00-17.00 ölçümleri & 185.3 lux & 537,2 lux & 1082 lux & 0,34 \\
\hline
\end{tabular}

Atölye B için dış ortam ölçümleri; güneşli havada saat 10.00-11.00'da $26.52 \mathrm{Klux}$, saat 16.00-17.00'da 7.58 Klux; bulutlu havada saat 10.00-11.00'da 5.67 Klux, 16.0017.00'da 8.87 Klux'tür.

Tablo 5: Atölye B- Doğal Aydınlatma Ölçüm Verileri

\begin{tabular}{|l|l|l|l|l|}
\hline Atölye B- Doğal Aydınlatma Ölçümleri & $\mathbf{E}_{\min }$ & $\mathbf{E}_{\text {ort }}$ & $\mathbf{E}_{\max }$ & $\begin{array}{l}\text { Düzgünlük } \\
\left(\mathbf{E}_{\min } / \mathbf{E}_{\text {ort }}\right)\end{array}$ \\
\hline Güneşli Hava Saat:10.00-11.00 ölçümleri & 164 lux & 404,4 lux & 1234 lux & 0,40 \\
\hline Bulutlu Hava Saat:10.00-11.00 ölçümleri & 51 lux & 241,8 lux & 718 lux & 0,21 \\
\hline Güneşli Hava Saat:16.00-17.00 ölçümleri & 55 lux & 230,4 lux & 659 lux & 0,23 \\
\hline Bulutlu Hava Saat:16.00-17.00 ölçümleri & 39 lux & 214,7 lux & 589 lux & 0,18 \\
\hline
\end{tabular}

Tablo 6: Atölye B- Yapay ve Doğal Aydınlatma Ölçüm Verileri

\begin{tabular}{|l|l|l|l|l|}
\hline Atölye B- Yapay Aydınlatma Ölçümleri & $\mathbf{E}_{\min }$ & $\mathbf{E}_{\text {ort }}$ & $\mathbf{E}_{\max }$ & $\begin{array}{l}\text { Düzgünlük } \\
\left(\mathbf{E}_{\min } / \mathbf{E}_{\text {ort }} \mathbf{~}\right.\end{array}$ \\
\hline Güneşli Hava Saat:10.00-11.00 ölçümleri & 403,4 lux & 669.1 lux & 1592 lux & 0,60 \\
\hline Bulutlu Hava Saat:10.00-11.00 ölçümleri & 285 lux & 442.7 lux & 813 lux & 0,64 \\
\hline Güneşli Hava Saat:16.00-17.00 ölçümleri & 319 lux & 462,2 lux & 766 lux & 0,69 \\
\hline Bulutlu Hava Saat:16.00-17.00 ölçümleri & 223 lux & 441.2 lux & 758 lux & 0.50 \\
\hline
\end{tabular}


Atölye F için dış ortam ölçümleri; güneşli havada saat 10.00-11.00'da $34.82 \mathrm{Klux}$, saat 16.00-17.00'da 5.66 Klux; bulutlu havada saat 10.00-11.00'da 7.32 Klux, 16.00 17.00 'da 6.15 Klux'tür.

Tablo 7: Atölye F- Doğal Aydınlatma Ölçüm Verileri

\begin{tabular}{|l|l|l|l|l|}
\hline Atölye F- Doğal Aydınlatma Ölçümleri & $\mathbf{E}_{\min }$ & $\mathbf{E}_{\text {ort }}$ & $\mathbf{E}_{\max }$ & $\begin{array}{l}\text { Düzgünlük } \\
\left(\mathbf{E}_{\min } / \mathbf{E}_{\text {ort }} \mathbf{)}\right.\end{array}$ \\
\hline Güneşli Hava Saat:10.00-11.00 ölçümleri & $14,91 \mathrm{KIx}$ & $24,36 \mathrm{KIx}$ & $27,82 \mathrm{KIx}$ & 0,61 \\
\hline Bulutlu Hava Saat:10.00-11.00 ölçümleri & $173 \mathrm{lux}$ & $630,4 \mathrm{lux}$ & $1332 \mathrm{lux}$ & 0,27 \\
\hline Güneşli Hava Saat:16.00-17.00 ölçümleri & $142 \mathrm{lux}$ & $536,1 \mathrm{lux}$ & $1208 \mathrm{lux}$ & 0,26 \\
\hline Bulutlu Hava Saat:16.00-17.00 ölçümleri & $112 \mathrm{lux}$ & $669,6 \mathrm{lux}$ & $1578 \mathrm{lux}$ & 0,16 \\
\hline
\end{tabular}

Tablo 8: Atölye F- Yapay ve Doğal Aydınlatma Ölçüm Verileri

\begin{tabular}{|l|l|l|l|l|}
\hline Atölye F- Yapay Aydınlatma Ölçümleri & $\mathbf{E}_{\min }$ & $\mathbf{E}_{\text {ort }}$ & $\mathbf{E}_{\max }$ & $\begin{array}{l}\text { Düzgünlük } \\
\left(\mathbf{E}_{\min } / \mathbf{E}_{\text {ort }}\right)\end{array}$ \\
\hline Güneşli Hava Saat:10.00-11.00 ölçümleri & $22.84 \mathrm{KIx}$ & $29,15 \mathrm{Klx}$ & $39.38 \mathrm{KIx}$ & 0,78 \\
\hline Bulutlu Hava Saat:10.00-11.00 ölçümleri & $450 \mathrm{lux}$ & 792,2 lux & $1486 \mathrm{lux}$ & 0,56 \\
\hline Güneşli Hava Saat:16.00-17.00 ölçümleri & $470 \mathrm{lux}$ & 784,6 lux & $1297 \mathrm{lux}$ & 0,59 \\
\hline Bulutlu Hava Saat:16.00-17.00 ölçümleri & 265 lux & 687,1 lux & 1245 lux & 0,38 \\
\hline
\end{tabular}

Atölye A ve Atölye B'de doğal aydınlatmanın olduğu durumda aydınlık düzeyi ve düzgünlük değerlerinin minimum değerlerin altında olduğu görülmüştür. Mevcut yapay aydınlatmanın kullanılması ile birlikte aydınlık düzeyi ortalamaları minimum değerin üzerine çıkarken, düzgünlük değerlerinin minimum değerin altında kaldığı durumlar görülmektedir. Bu duruma özellikle Atölye A'da daha sık rastlanmaktadır. Atölye F'de doğal aydınlatma ile aydınlık düzeyi minimum değerin üzerinde çıkmıştır. Ancak düzgünlük değerleri minimum değerin altındadır. Yapay aydınlatmanın kullanıldığı durumda ise aydınlık düzeyi ortalaması daha da artmıştır. Buna karşın minimum düzgünlük değerinin sağlanamadığı durumlar bulunmaktadır.

Yapılan değerlendirme sonucunda atölyelerin ortalama aydınlık seviyelerinin mevcut yapay aydınlatma ile birlikte standarda uygun olduğu görülmüştür. Ancak düzgünlük değerinin sağlanamamış olması atölye genelinde homojen bir aydınlık seviyesi olmadığını göstermektedir.

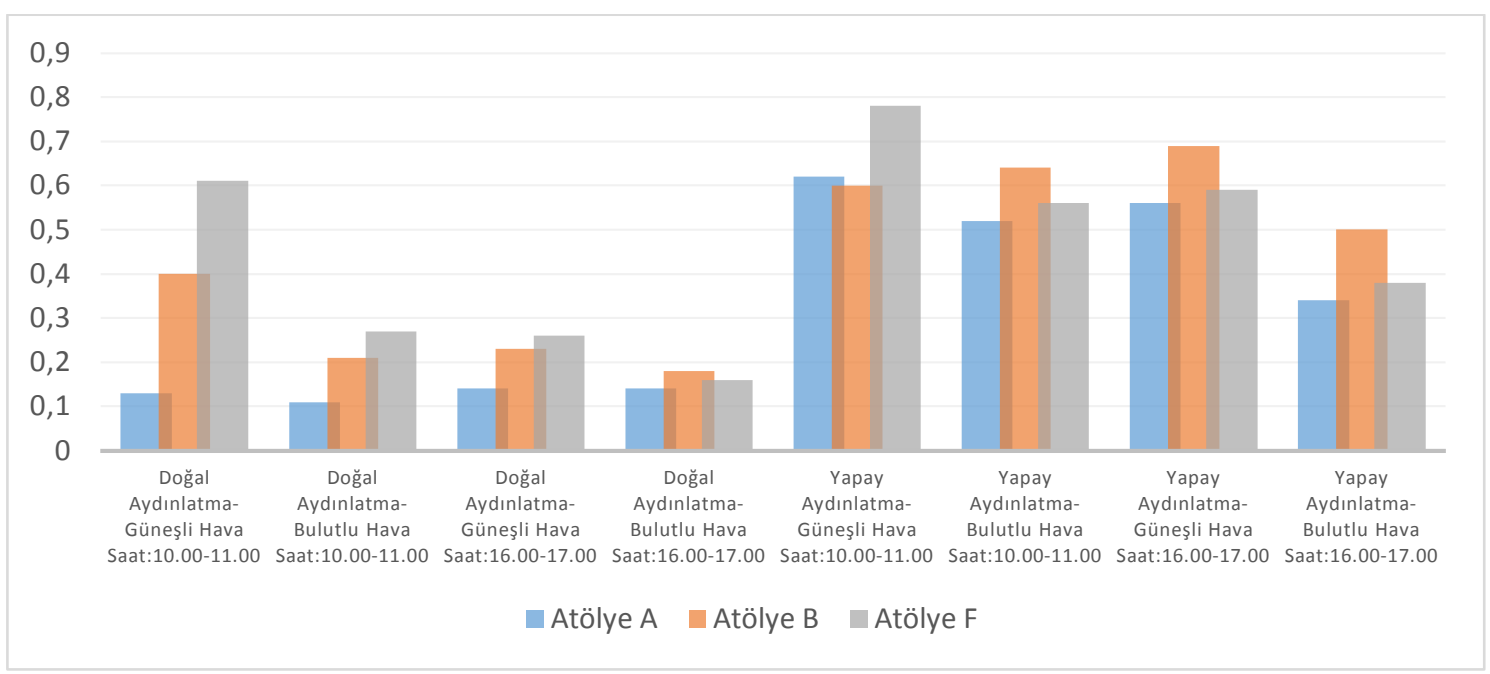

Grafik 2: Atölyelerin Düzgünlük Değerlerinin Karşılaştırması 
Tüm bileşenler ele alındığında Atölye F'nin diğer atölyelere göre standartları büyük oranda sağladığı görülmüştür. Ancak F'de güneşli hava ölçümlerinde Klux cinsinden değerlere rastlanmıştır. Bu durum termal ve görsel konforu olumsuz yönde etkilemektedir. Bu sebeple atölyede düzgün dağılımlı bir aydınlık düzeyi oluşması için güneş kırıcı, ışık rafı ya da güneş yönlendirici cam kullanııması önerilmiştir.

Atölye A ve Atölye B'nin aydınlık seviyesi dağılımının homojen olmadığı görülmüştür. Bu sebeple yapılacak olan iyileştirme homojenliği sağlamak amacıyla bölgesel olarak düşünülmelidir. Atölye A'nın minimum aydınlık düzeyi ve düzgünlük değerleri diğer atölyelere göre daha düşüktür(Grafik 2). İyileştirme çalışması için daha riskli verilere sahip olan Atölye A seçilmiştir.

\subsection{Atölye A mevcut durum ölçüm verileri}

Riskli görülen Atölye A'nın ortama aydınlık seviyesinin 300 luxe yakın değerler olduğu görülmüştür. Buna karşın ölçülen min. değerler bu seviyenin çok altında kalmıştır. Bu sebeple atölyede yapılacak öneri ortalama değere göre değil, bölgesel verilere göre yapılmalıdır. Bu doğrultuda noktasal veriler grafiklere aktarılmıştır ve atölyede iyileştirilmesi gereken bölgelerin tespit edilmesi amacıyla minimum ve maksimum değerler belirlenmiştir.

Min. değer olarak görsel konfor koşullarını sağlamak amaçlanmış ve TS EN 124641:2013 standardındaki min. değer olan 300 lux alınmıştır. Maksimum değer belirlenirken literatürde görsel ve termal konforu olumsuz etkileyeceği için sınır olarak 2000 lux görülmüştür (Nabil ve Mardaljevic, 2005). Ancak yapılacak olan çalışmada görsel konforun yanı sıra enerji verimliliği sağlanması amaçlanmıştır. Bu sebeple Tablo 1'deki istenilen min. lux değerlerinin üstünde ve mevcutta ölçülen maks. değerlere yakın olan 750 lux maksimum değer olarak kabul edilmiştir.
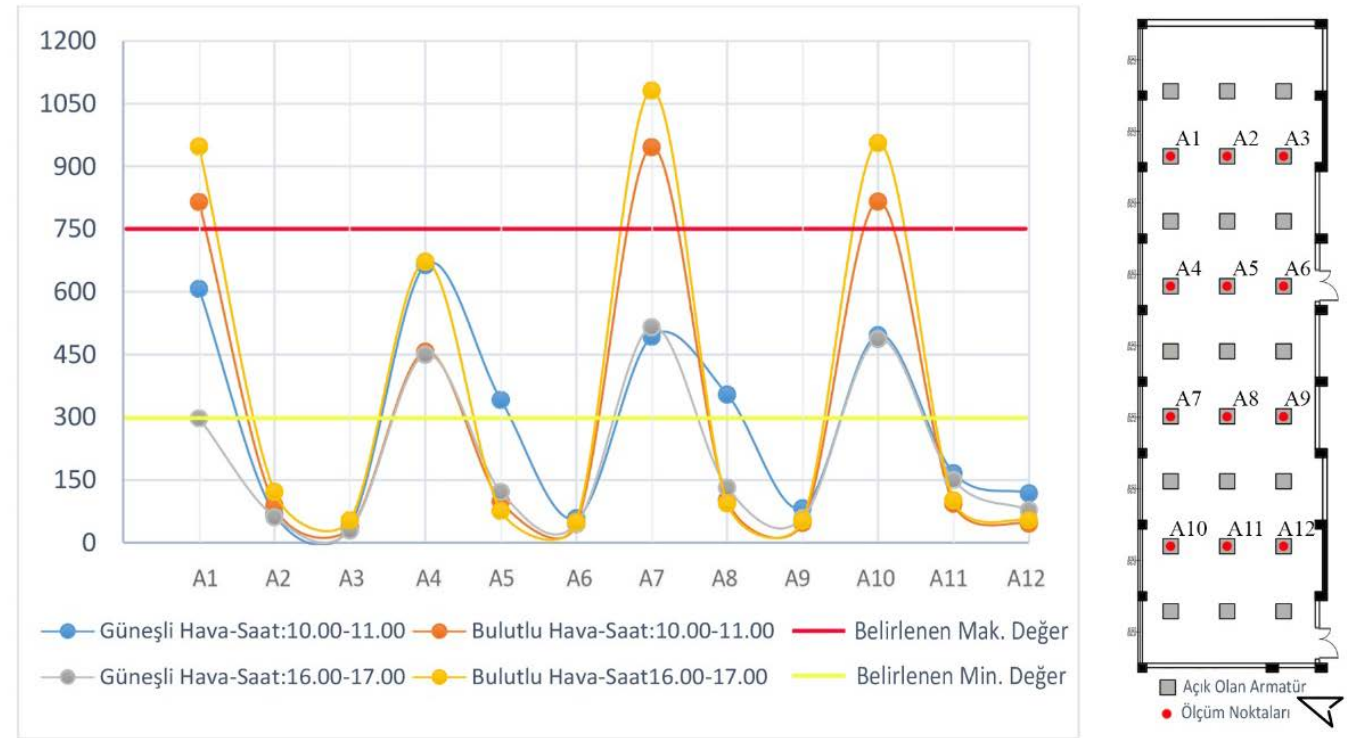

Grafik 3: Atölye A'da sadece doğal aydınlatmanın olduğu durumda ölçüm noktalardaki aydınlık seviyeleri atölye aydınlatma planı ve ölçüm noktalarının plandaki konumu 

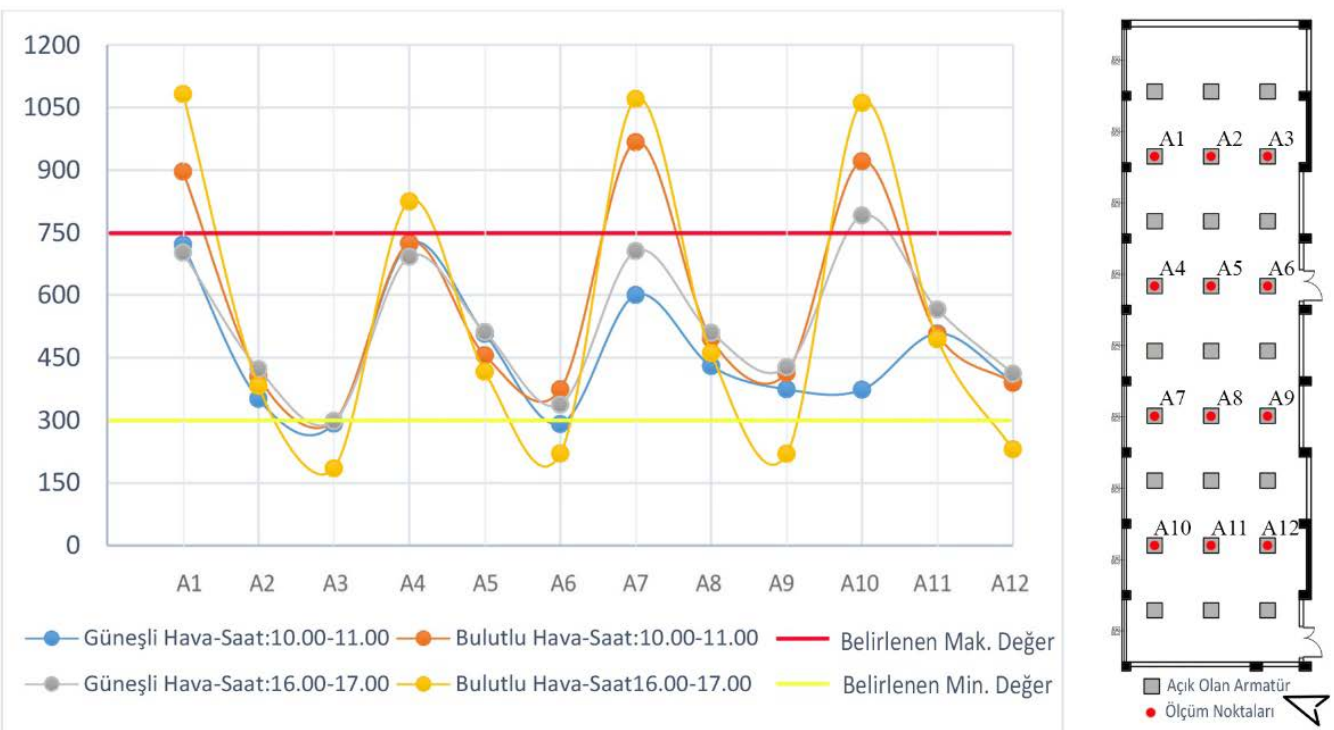

Grafik 4: Atölye A'da yapay aydınlatmanın açık olduğu durumda ölçüm noktalardaki aydınlık seviyeleri atölye aydınlatma planı ve ölçüm noktalarının plandaki konumu

$\mathrm{Bu}$ ölçümlerde sadece doğal aydınlatmanın olduğu durumda genel olarak pencere kenarındaki noktaların ( $A 1, A 4, A 7, A 10)$ belirlenen max. aydınlık düzeyi değerin üzerinde olduğu, duvar kenarındaki ve orta sıradaki noktaların (A2, A3, A5, A6, A8, A9, A11, A12) min. aydınlık düzeyi değerin altında olduğu görülmüştür. Tüm yapay aydınlatmanın açık olduğu durumda ise pencere kenarındaki noktaların aydınlık seviyelerinin daha da arttığı, orta sıradaki noktaların (A2, A5, A8, A11) belirlenen aydınlık düzeyi aralığına eriştiği ancak duvar kenarındaki noktaların (A3, A6, A9, A12) bazı durumlarda belirlenen aydınlık düzeyi aralığına erişirken diğer durumlarda ise min. aydınlık düzeyi değerinin altında olduğu görülmüştür.

\subsection{Atölye A'da mevcut aydınlatma planı üzerinden açılış seçenekleri denemesi}

Riskli olarak kabul edilen Atölye A'da ilk hedeflenen mevcut aydınlatma sisteminin yeterliliğini ölçmektir. Bu sebeple mevcut aydınlatma planı ve anahtar düzeni üzerinden durum denemeleri yapılmıştır.

Atölye A'da ölçüm sırasında mevcut aydınlatma planı üzerinden açılış seçenekleri oluşturulmuştur. Ölçümler incelendiğinde 16.00-17.00 ölçüm verilerinin 10.00-11.00 ölçüm verilerine göre daha düşük olduğu görülmüştür. Bu sebeple ölçüm sırasında min. aydınlık düzeyinin altında değerlere sahip olan noktaların bulunduğu bölgelerdeki armatürler farklı seçenek grupları ile açılmış ve sonuçlar değerlendirilmiştir.

Atölye A'da aydınlatma için 27 adet armatür kullanılmıştır, bu armatürler 6 anahtar ile açılmaktadır. Durum 1'de yalnızca 1. anahtar açılmıştır, Durum 2'de 2.- 3. ve 4. anahtarlar açılmış, Durum 3'te 1.- 2.- 3. ve 4. anahtalar açılmıştır (Şekil-3). 


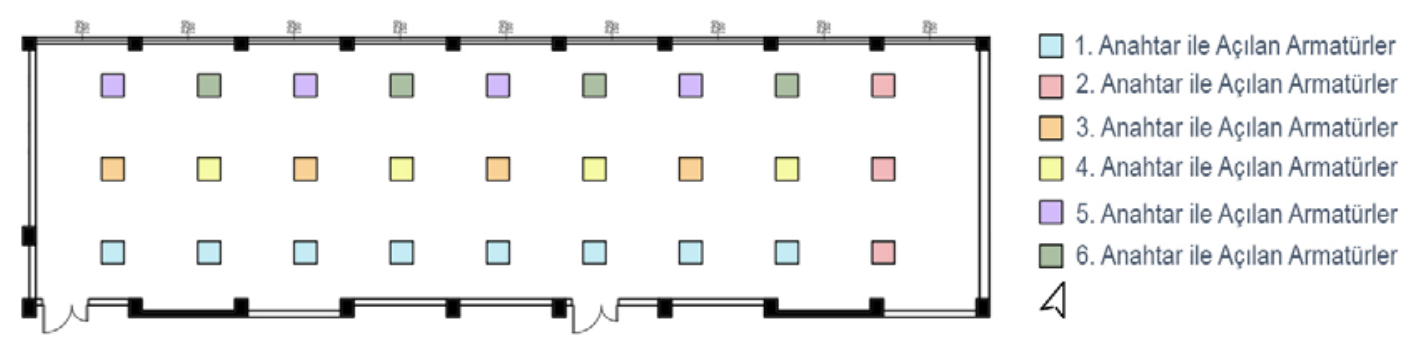

Şekil 3: Atölye A aydınlatma planı ve armatürlerin açılışını gösteren anahtar düzeni
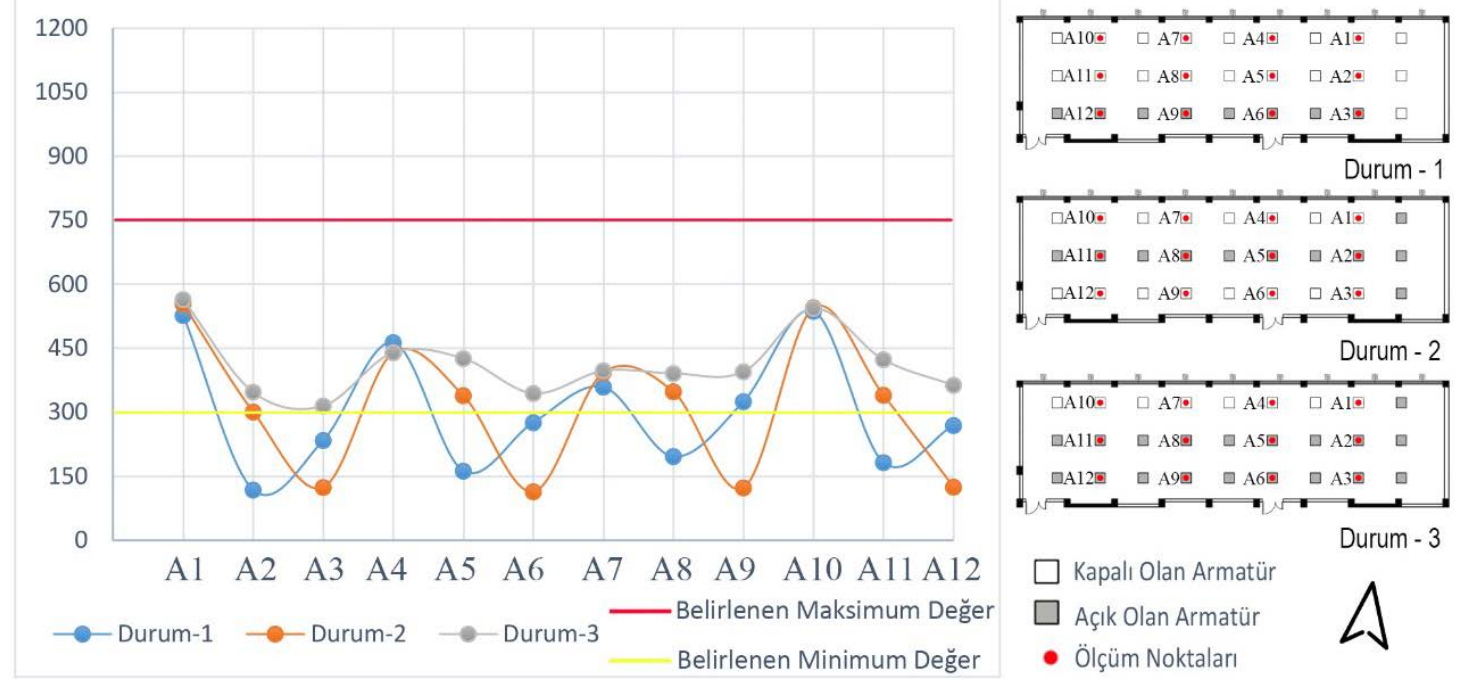

Grafik 5: Atölye A'da güneşli hava 16.00-17.00 ölçümleri yapay aydınlatmanın Durum 1- 2- 3 açılış seçenekleri
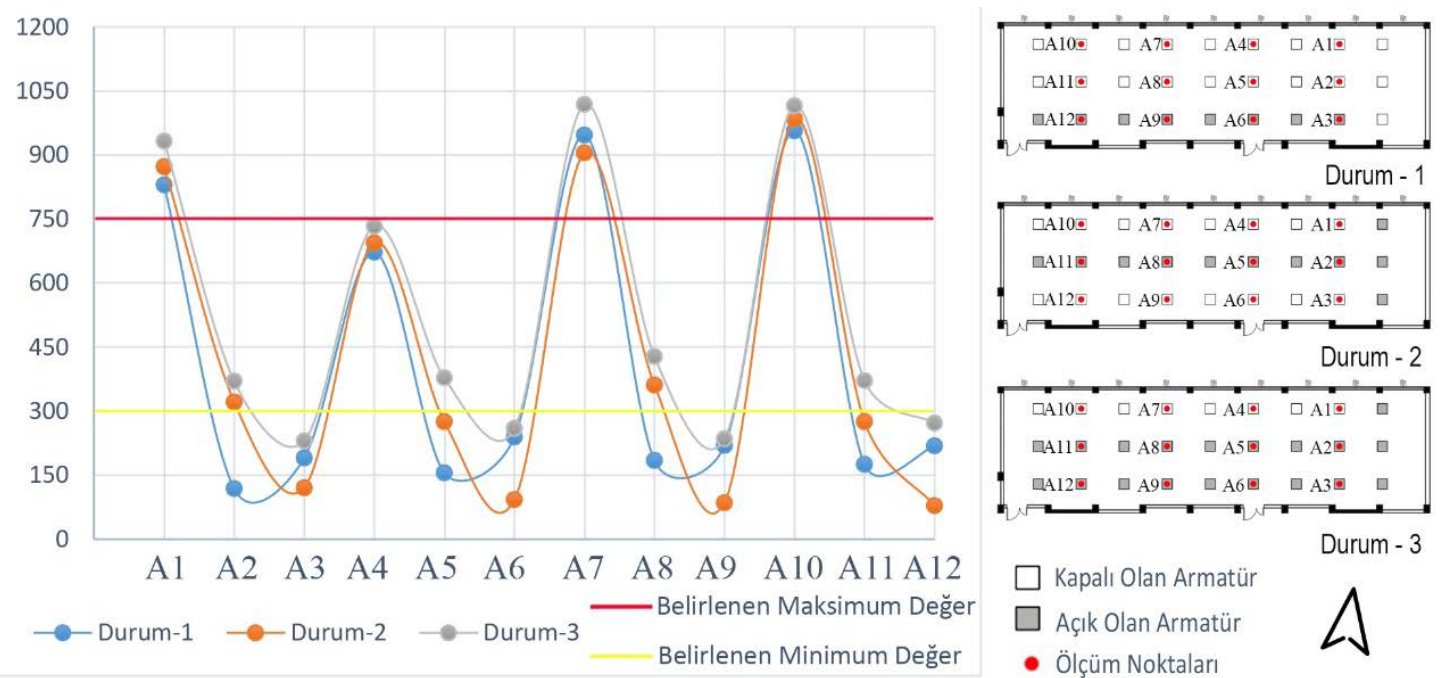

Grafik 6: Atölye A'da bulutlu hava 16.00-17.00 ölçümleri yapay aydınlatmanın Durum 1- 2- 3 açılış seçenekleri

Atölye A'da yapılan ölçümler sonucu duvar kenarındaki ve orta sıradaki noktalarda pencere kenarındaki noktalara göre daha düşük sonuçlar elde edilmiştir. Bu sebeple ilk olarak Durum 1 denenmiş ancak yeterli olmadığı görülmüştür. Sonrasında ise Durum 2 denenmiş orta sıradaki çoğu noktanın aydınlık seviyeleri belirlenen aralıkta iken bazı noktalar ile duvar kenarındaki bütün noktalar için yeterli olmadığı görülmüştür. Son olarak Durum 3 denenmiş, güneşli havada bütün noktalar için, bulutlu havada ise 
pencere kenarındaki ve orta sıradaki noktalar için yeterliyken duvar kenarındaki noktalar için yeterli olmadığı görülmüştür. Atölyedeki denemelerden elde edilen verilere göre mevcut armatürler ve aydınlatma planının kullanımı uygun değildir.

\section{5. ÖNERI}

Denemeler sonucunda çıkan veriler doğrultusunda DIALux Evo programı üzerinden aydınlatma elemanının aydınlatma gücünün ve türünün değiştirildiği simülasyon denemeleri yapılmıştır.

\subsection{DIALux Evo 8.2 programında öneri simülasyonları}

DIALux Evo² programı üzerinden Atölye A için öneriler geliştirilmiştir. Programda doğal ışık hesaplaması için tarih, saat ve gök tipi (açık gök, ortalama gök, kapalı gök) seçilmiş, bu verilere ek olarak hesaplama yapılacak yapının konumu (enlem, boylam), zaman dilimi ve kuzey yönü belirlenmiştir.

DIALux Evo programında aydınlık seviyesini istenilen düzeye getirme amacıyla iki farklı yönteme sahip öneriler denenmiştir. Önerilerlerde dimmerlenme durumu ve farklı bir aydınlatma sisteminin oluşturacağı etkiler ayrı olarak gözlemlenmek istenmiştir. Bu sebeple Öneri 1'de mevcut aydınlatma türünde ve planında dış koşullar ile işlevsel intiyaçlara göre ayarlanabilmesi için dimmerli armatür kullanılmıştır. Öneri 2'de ise floresana göre etkinlik faktörü $(\mathrm{Im} / \mathrm{w})$ daha iyi olan LED armatür kullanılmıştır (Resim 3). Öneri 1 ve Öneri 2 için anahtar planı hazırlanmış böylece atölyenin o anki aydınlık düzeyi intiyacına göre açılması gereken armatürlerin manuel olarak ayarlanabilmesi sağlanmıştır (Şekil 4, Şekil 5).
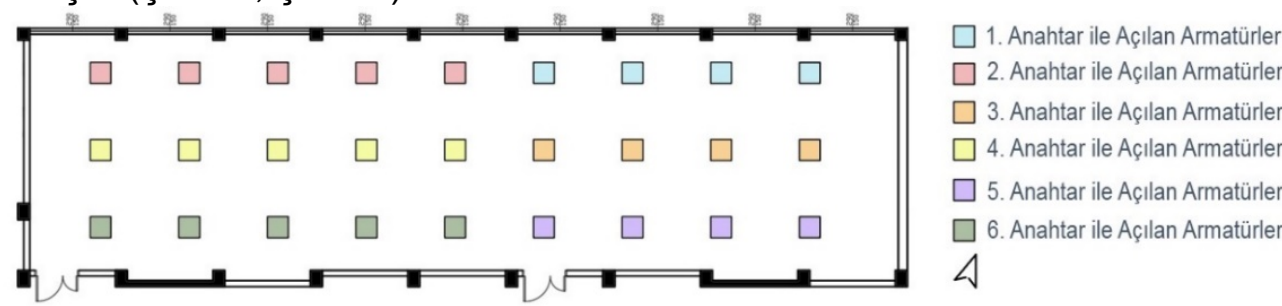

Şekil 4: Atölye A'da Öneri 1 aydınlatma planı ve armatürlerin açılışını gösteren anahtar düzeni

Öneri 1'de enerji verimliliğini sağlamak amacıyla mevcut durumda kullanılan armatürün watt(birim zamanda tüketilen enerji miktarı) değeri değiştirilmeden lümen(birim zamanda saçılan ışık miktarı) değeri arttırılmış ve ayarlanabilir hale getirilmiştir.

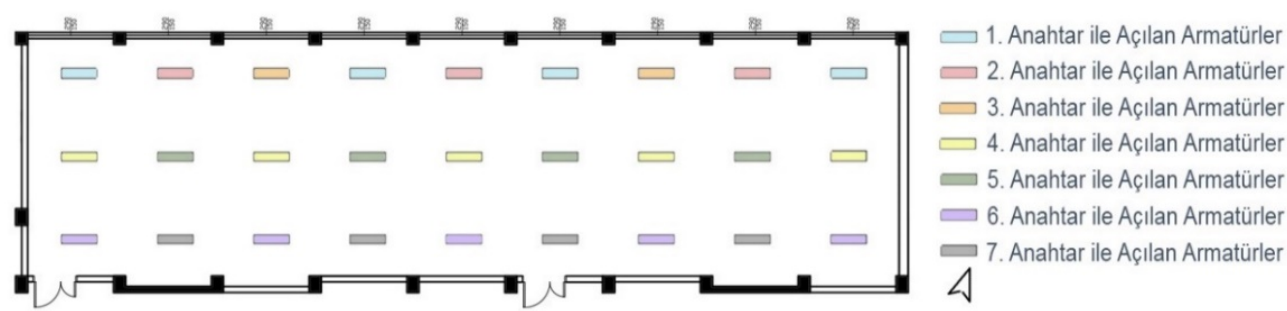

Şekil 5: Atölye A'da Öneri 2 aydınlatma planı ve armatürlerin açılışını gösteren anahtar düzeni

Öneri 2'de mevcut durumda kullanılan armatürün yerine enerji tüketimi daha az ve Im değeri daha fazla olan bir armatür türü kullanılmıştır (Şekil 5). Önerilerin amacı daha az enerji tüketimiyle optimum görsel konfor koşullarına ulaşabilmektir.

\footnotetext{
${ }^{2}$ Bu çalışmada DIALux Evo 8.2 programı kullanıımıştır. DIALux, DIAL (Alman Uygulamalı Aydınlatma Teknolojisi Enstitüsü) tarafından 1994 yılında Almanya'da geliştirilmiş aydınlatma tasarım yazılımıdır.
} 
Tablo 9: Mevcut durum, Öneri 1 ve Öneri 2'de kullanılan armatür türleri ${ }^{3}$

Mevcut durum

27 adet, $60 \times 60 \mathrm{~cm}$ çift parabolik floresan armatür (4x800 lümen, $4 \times 14 \mathrm{~W}$ ) kullanılmıştır. Etkinlik Faktörü: $54,14 \mathrm{Im} / \mathrm{W}$ Aydınlatma Gücü Yoğunluğu (LPD): $6.38 \mathrm{~W} / \mathrm{m}^{2}$

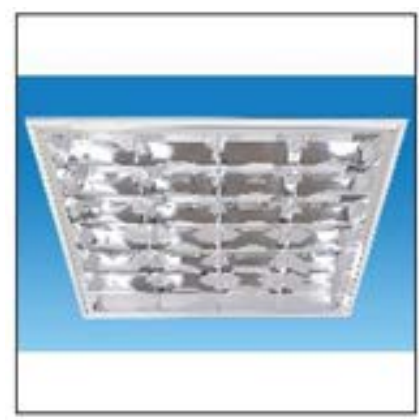

\section{Öneri 1}

27 adet, dimmerli $60 \times 60 \mathrm{~cm}$ çift parabolik floresan armatür (4x1200 lümen, 4x14 W) kullanılmıştır.

Etkinlik Faktörü: 85,71 Im/W

Aydınlatma Gücü Yoğunluğu (LPD): $6.38 \mathrm{~W} / \mathrm{m}^{2}$

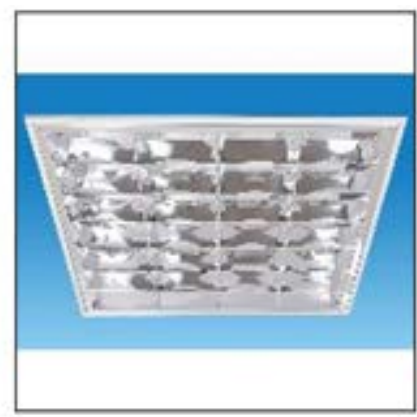

\section{Öneri 2}

27 adet $120 \times 30 \mathrm{~cm}$ led armatür (4100 lümen, $31 \mathrm{~W}$ ) kullanılmıştır.

Etkinlik Faktörü: 132,25 Im/W Aydınlatma Gücü Yoğunluğu (LPD): $3.53 \mathrm{~W} / \mathrm{m}^{2}$

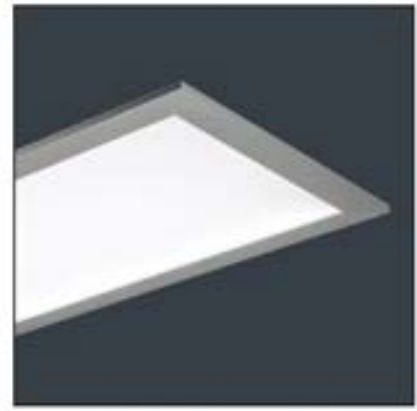

\subsection{Mevcut durum ile önerilerin karşılaştırılması}

Mevcut durum ile karşılaştırma yapılırken güneşli hava için programda açık gök tipi seçilmiş, tarih olarak 10.12.2019 belirlenmiştir. Bulutlu hava için programda kapalı gök tipi seçilmiş, 23.12.2019 tarihi ayarlanmıştır. Saat olarak iki gök koşulu için de ölçüm yapılan saat olan 10.00 ve 16.00 girilmiştir.

DIALux programından elde edilen eşaydınlık eğrileri görsel konfor koşullarını, aydınlatma güç yoğunluğu (LPD) değeri ise enerji tüketimini karşılaştırmak amacıyla kullanılmıştır.

\footnotetext{
${ }^{3}$ Tabloda, aydınlatma gücü yoğunluğu (Lighting Power Density, LPD), ışık sahneleri ve bunların kısma durumları dikkate alınmadan, tüm armatürlerin açık olduğu durumda $\mathrm{m}^{2}$ başına harcanan enerji miktarını açıklar (LPD = Güç /Alan = $\left.\mathrm{W} / \mathrm{m}^{2}\right)$.
} 


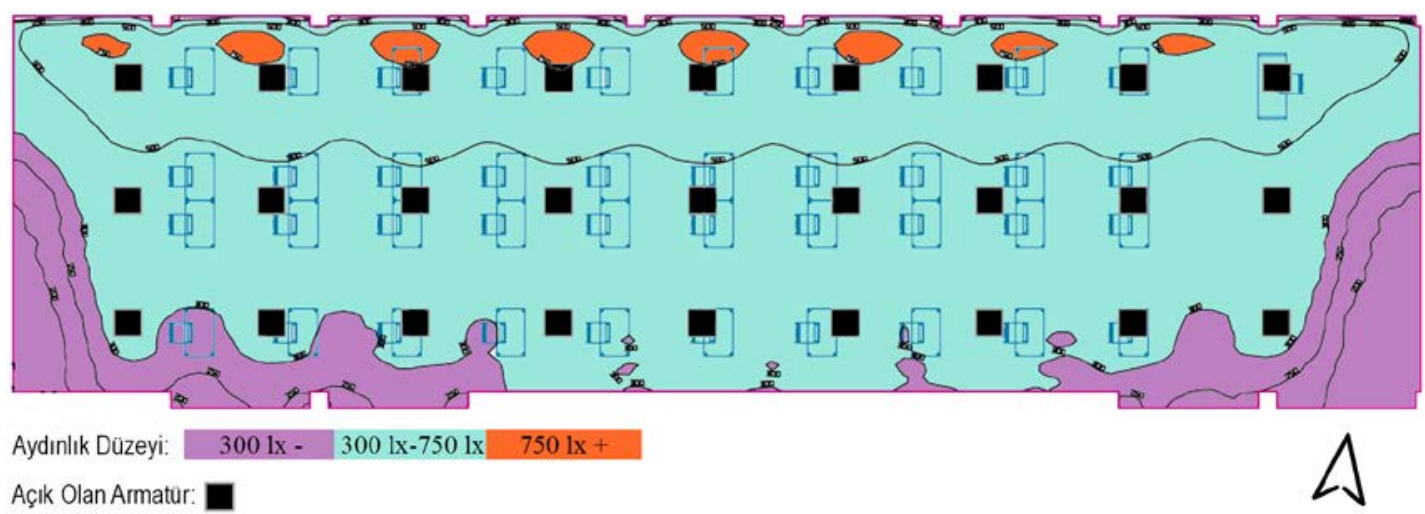

Açık Olan Armatur:

Şekil 6.a: Atölye A mevcut durum - LPD: $6.38 \mathrm{~W} / \mathrm{m}^{2}$

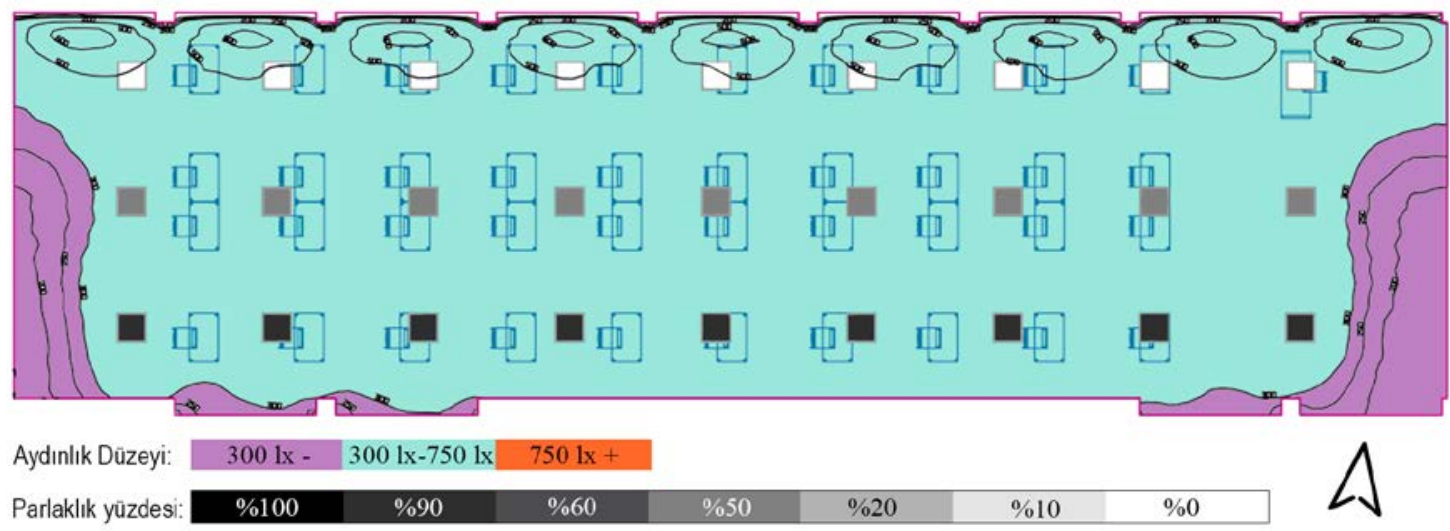

Şekil 6.b: Atölye A mevcut aydınlatma planının iyileştirilmesi (Öneri 1) - LPD: $2.97 \mathrm{~W} / \mathrm{m}^{2}$

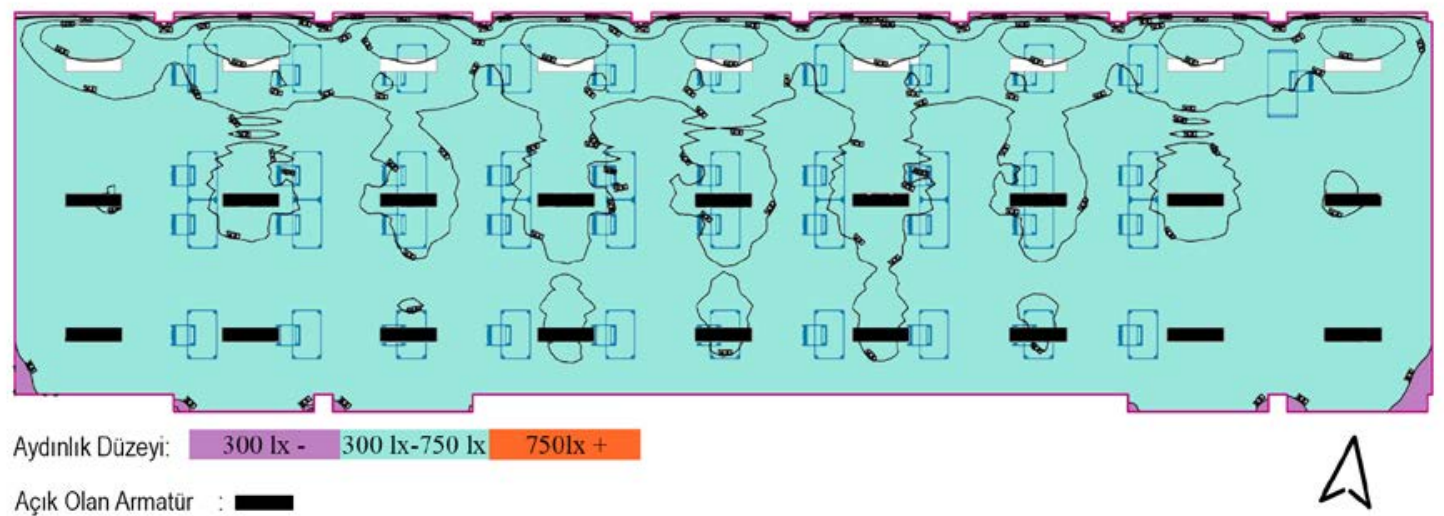

Şekil 6.c: Atölye A farklı tür aydınlatma elemanının kullanımı (Öneri 2) -LPD : $2.35 \mathrm{~W} / \mathrm{m}^{2}$ Şekil 6: Güneşli hava saat 10.00-11.00 ölçümleri mevcut durum ile önerilerin karşılaştırılması

Güneşli hava saat 10.00-11.00 ölçümleri için yapılan simülasyonlarda Öneri 1'de armatürler duvar kenarı, orta sıra olmak üzere intiyaca göre belirlenmiş 2 farklı parlaklık yüzdesine sahip olacak şekilde ayarlanmış, pencere kenarındaki armatürler açılmamıştır. Çalışma düzlemi mevcut duruma göre optimum aydınlık düzeyine getirilmeye çalışılmıştır. Fakat duvar kenarındaki köşelerde min. aydınlık düzeyinin altında kalan bölgeler vardır. Öneri 2'de ise duvar kenarındaki ve orta sıradaki armatürler açılmış ve çalışma düzlemi belirlenen aydınlık düzeyi aralığına getirilmiştir. LPD değerleri incelendiğinde, enerji tüketimi mevcut duruma göre Öneri 1'de \%53, Öneri 2'de ise $\% 63$ oranında azalmıştır. 


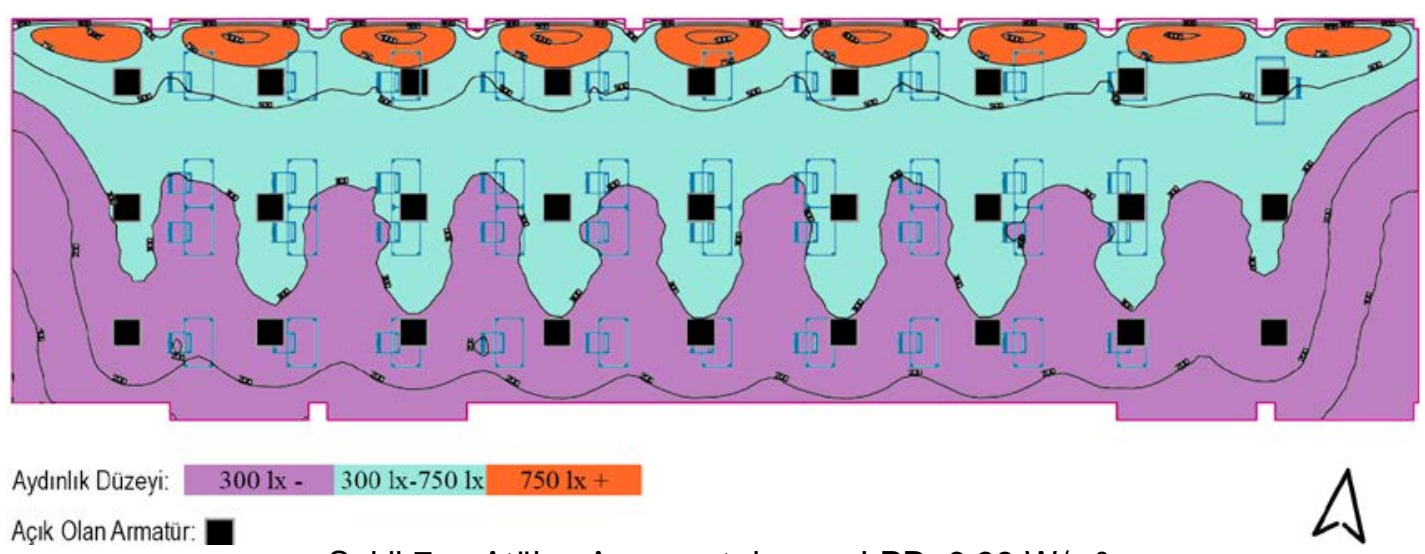

Şekil 7.a: Atölye A mevcut durum- LPD: $6.38 \mathrm{~W} / \mathrm{m}^{2}$

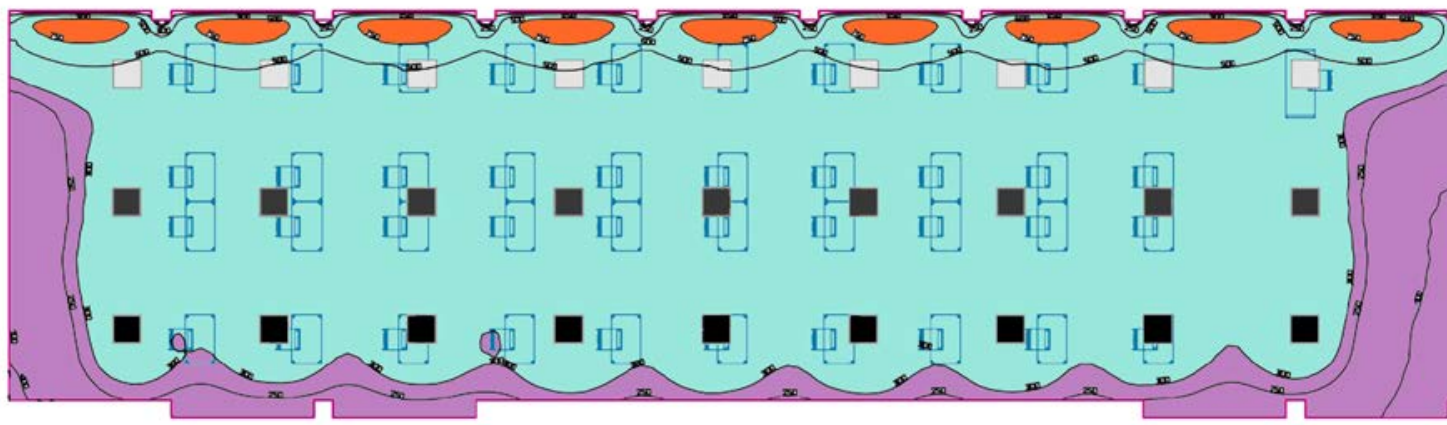

Aydınlık Düzeyi: $\quad 300 \mathrm{~lx}-300 \mathrm{~lx}-750 \mathrm{~lx} \quad 750 \mathrm{~lx}+$

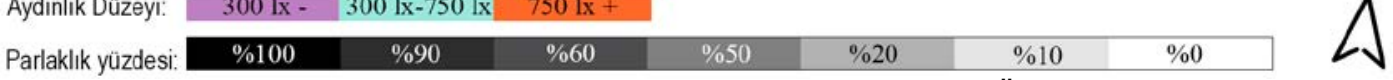

Şekil 7.b: Atölye A mevcut aydınlatma planının iyileştirilmesi (Öneri 1) - LPD: 4.25 W/m

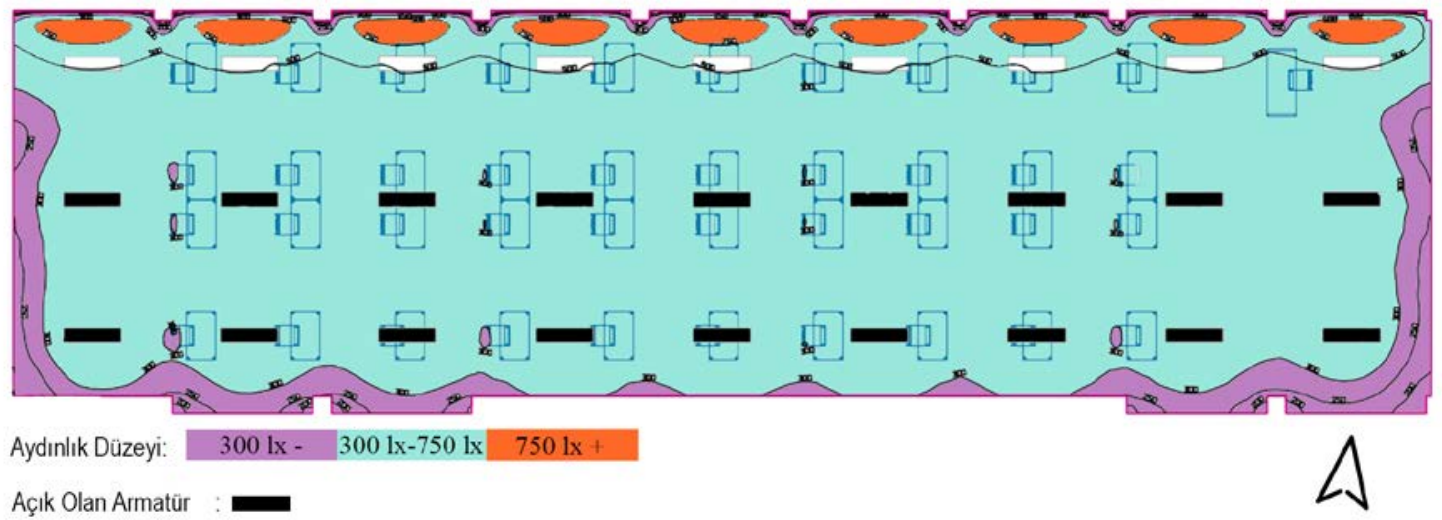

Şekil 7.c: Atölye A farklı tür aydınlatma elemanının kullanılması (Öneri 2) - LPD: $2.35 \mathrm{~W} / \mathrm{m}^{2}$ Şekil 7: Bulutlu hava saat 10.00-11.00 ölçümleri mevcut durum ile önerilerin karşılaştırılması

Bulutlu hava saat 10.00-11.00 ölçümleri için yapılan simülasyonlarda, Öneri 1'de armatürler duvar kenarı, orta sıra ve pencere kenarı olmak üzere ihtiyaca göre belirlenmiş 3 farklı parlaklık yüzdesine sahip olacak şekilde ayarlanmıştır. Öneri 2'de ise duvar kenarındaki ve orta sıradaki armatürler açılmış ve atölye genelinde çalışma düzlemi mevcut duruma göre optimum aydınlık düzeyine getirilmeye çalışılmıştır. Fakat duvar kenarı ve köşelerde min. aydınlık düzeyinin altında kalan bölgeler vardır. LPD değerleri incelendiğinde, enerji tüketimi mevcut duruma göre Öneri 1'de \%33, Öneri 2 'de ise \%63 oranında azalmıştır. 


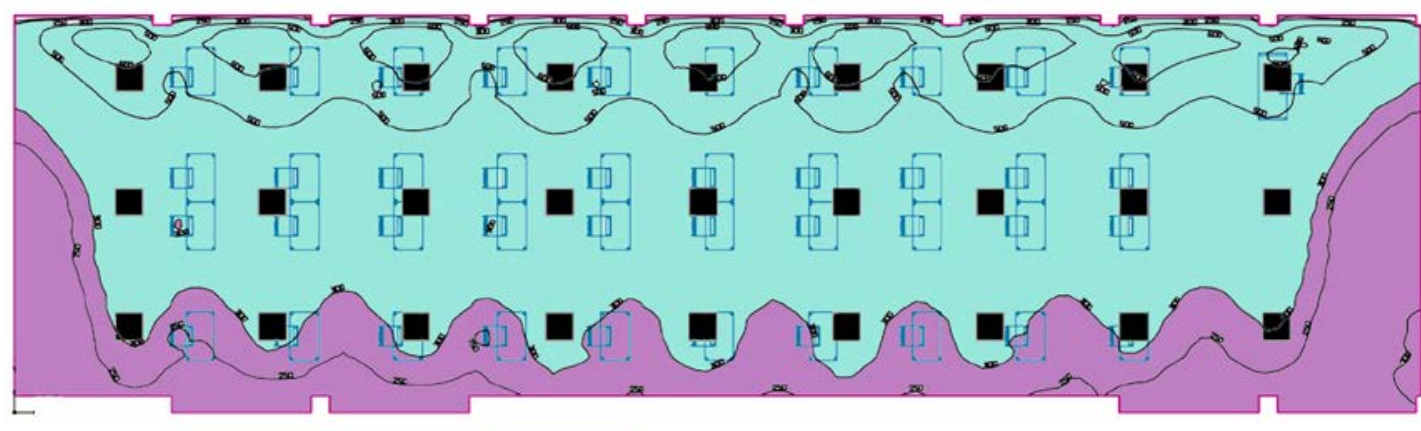

Aydınlık Düzeyi: $\quad 300 \mathrm{~lx}-\quad 300 \mathrm{~lx}-750 \mathrm{~lx} \quad 750 \mathrm{~lx}+$

Açik Olan Armatür:

Şekil 8.a: Atölye A mevcut durum - LPD: $6.38 \mathrm{~W} / \mathrm{m}^{2}$
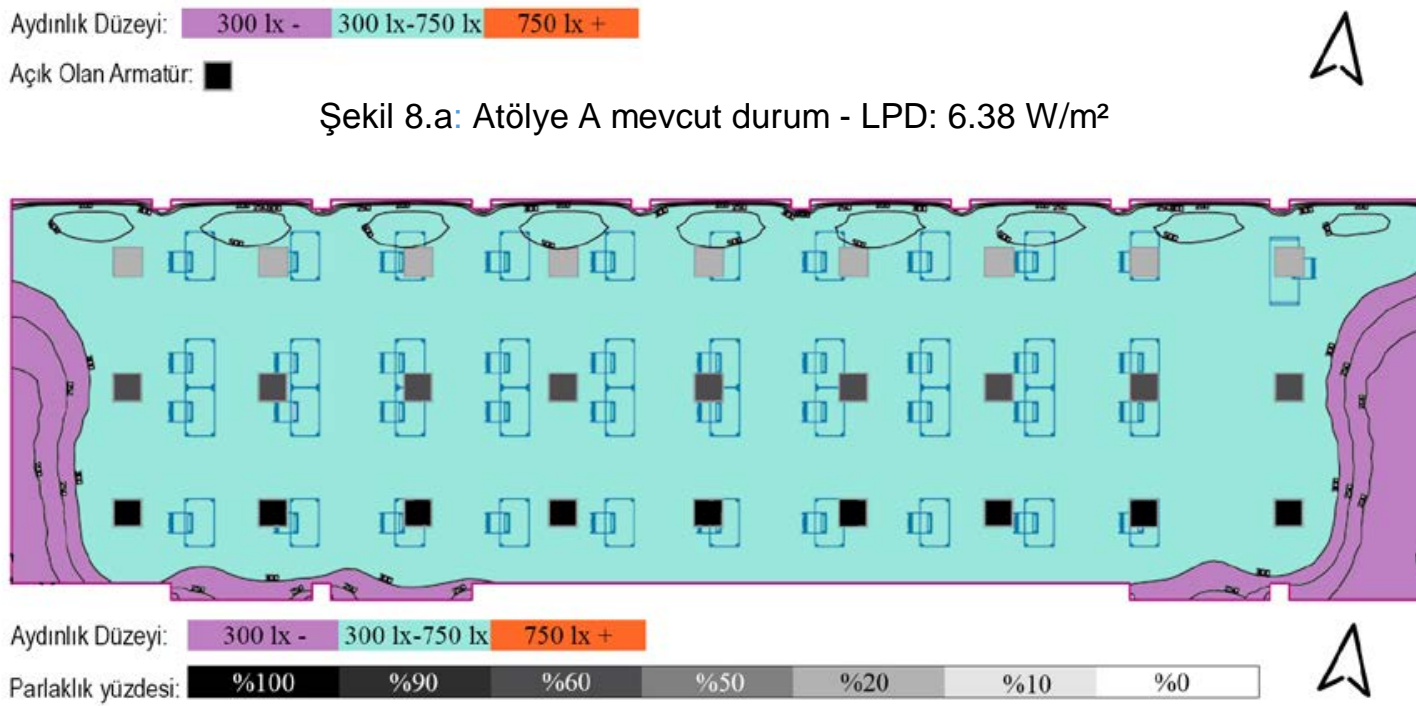

Şekil 8.b: Atölye A mevcut aydınlatma planının iyileştirilmesi (Öneri 1) - LPD: 3.82 W/m²

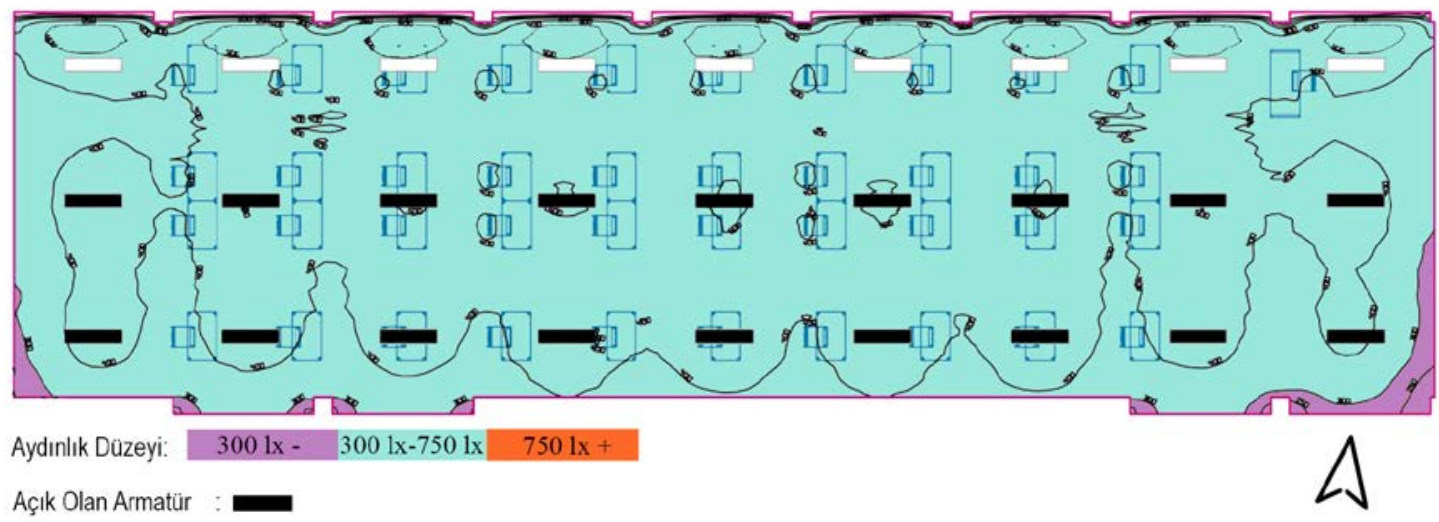

Şekil 8.c: Atölye A farklı tür aydınlatma elemanının kullanılması (Öneri 2) - LPD: 2.35 W/m² Şekil 8: Güneşli hava saat 16.00-17.00 ölçümleri mevcut durum ile önerilerin karşılaştırılması

Güneşli hava saat 16.00-17.00 ölçümleri için yapılan simülasyonlarda, Öneri 1'de armatürler duvar kenarı, orta sıra ve pencere kenarı olmak üzere ihtiyaca göre belirlenmiş 3 farklı parlaklık yüzdesine sahip olacak şekilde ayarlanmıştır. Öneri 2'de ise duvar kenarındaki ve orta sıradaki armatürler açılmıştır. Atölye genelinde çalışma düzlemi mevcut duruma göre optimum aydınlık düzeyine getirilmiştir. Fakat Öneri 1'de duvar kenarındaki köşelerde min. aydınlık düzeyinin altında kalan bölgeler vardır. LPD değerleri incelendiğinde, enerji tüketimi mevcut duruma göre Öneri 1'de \%40, Öneri 2 'de ise $\% 63$ oranında azalmıştır. 


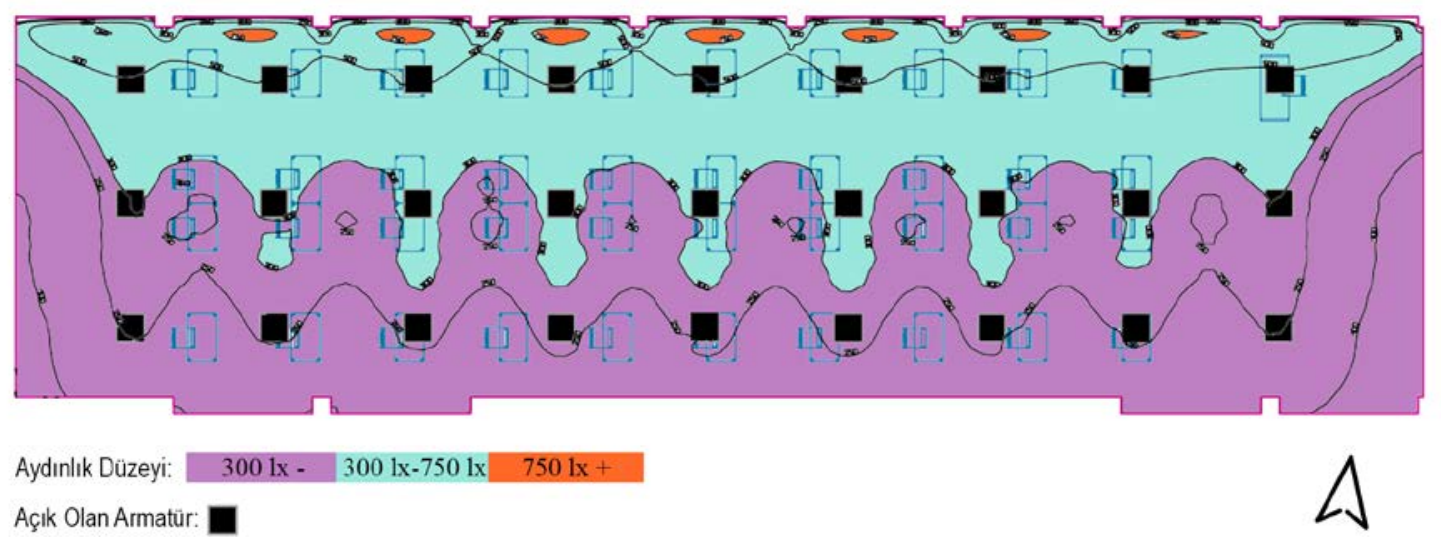

Şekil 9.a: Atölye A mevcut durum- LPD: $6.38 \mathrm{~W} / \mathrm{m}^{2}$

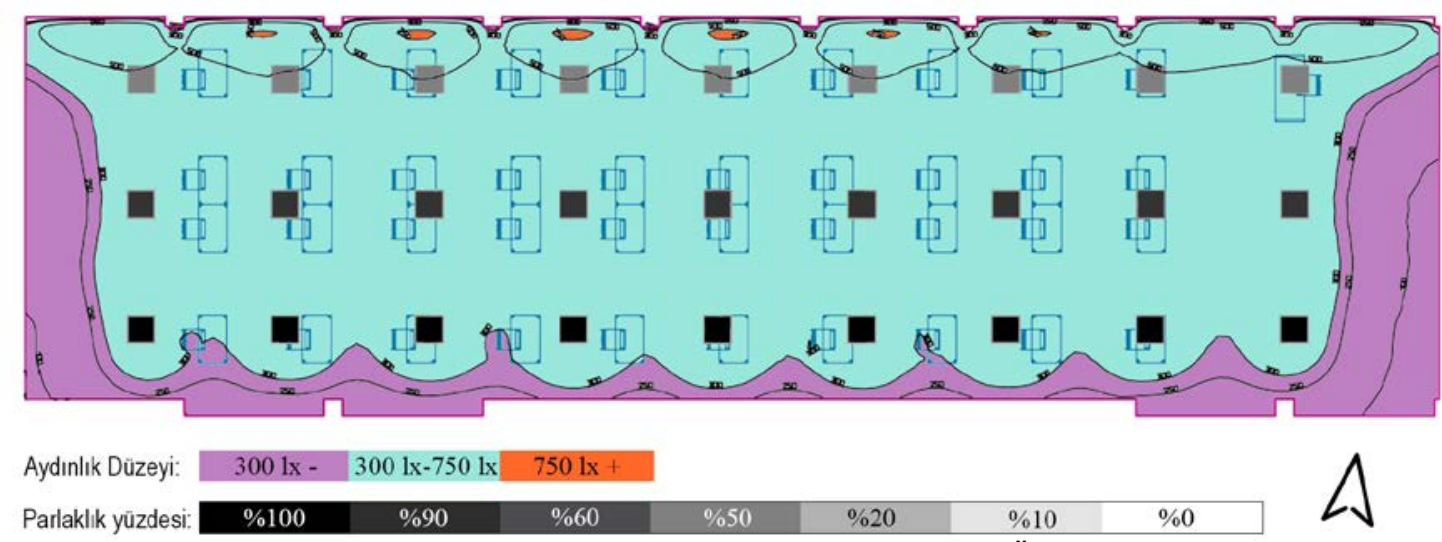

Şekil 9.b: Atölye A mevcut aydınlatma planının iyileştirilmesi (Öneri 1) - LPD: 5.10 W/m²

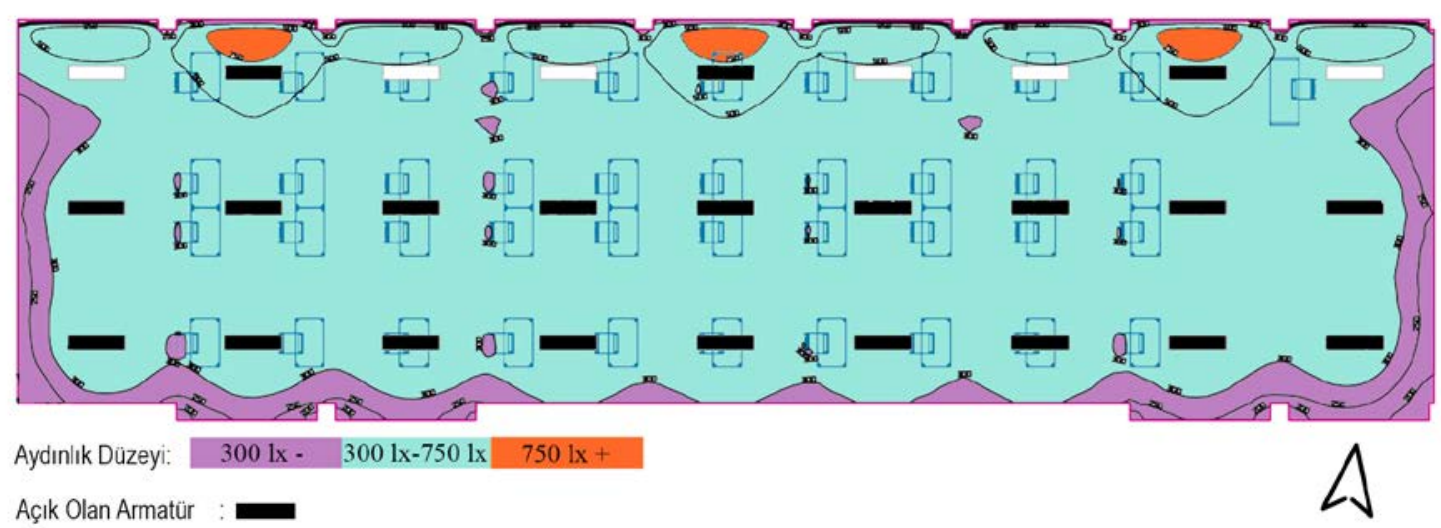

Şekil 9.c: Atölye A farklı tür aydınlatma elemanının kullanılması (Öneri 2) - LPD: $2.74 \mathrm{~W} / \mathrm{m}^{2}$ Şekil 9: Bulutlu hava saat 16.00-17.00 ölçümleri mevcut durum ile önerilerin karşılaştırılması

Bulutlu hava saat 16.00-17.00 ölçümleri için yapılan simülasyonlarda, Öneri 1'de armatürler duvar kenarı, orta sıra ve pencere kenarı olmak üzere ihtiyaca göre belirlenmiş 3 farklı parlaklık yüzdesine sahip olacak şekilde ayarlanmıştır. Öneri 2'de ise duvar kenarındaki ve orta sıradaki tüm armatürler ile pencere kenarındaki 2. Anahtara bağlı armatürler açılmıtır. Her iki öneride atölye genelinde çalışma düzlemi mevcut duruma göre optimum aydınlık düzeyine getirilmiştir. Fakat duvar kenarındaki köşelerde min. aydınlık düzeyinin altında kalan bölgeler vardır. Öneri 2'de ise pencere 
kenarında açık olan armatürlerin olduğu bölgelerde belirlenen max. aydınlık düzeyi değerinin üstüne çıkılmıştır. LPD değerleri incelendiğinde, enerji tüketimi mevcut duruma göre Öneri 1'de \%20, Öneri 2'de ise \%57 oranında azalmıştır.

Yapılan tüm simülasyonlarda, LPD değerleri ve eşaydınlık eğrileri incelendiğinde önerilerin mevcut duruma göre enerji tüketimini azaltarak görsel konforun sağlandığı gözlemlenmiştir.

\section{DEĞERLENDIRME VE SONUÇ}

KOÜ Mimarlık ve Tasarım Fakültesindeki seçili atölyelerde güneşli ve bulutlu hava olmak üzere belirlenen saat aralıklarında (10.00-11.00, 16.00-17.00) ölçüm yapılmıştır. Atölye F'de yapılan ölçümler sonucunda minimum aydınlık düzeyine ulaşmada doğal aydınlatma yeterli olmuştur. Minimum düzgünlük değerine ise mevcut yapay aydınlatma ile erişilmiştir. Atölye A'da ve Atölye B'de istenilen aydınlık düzeyi doğal aydınlatma ile sağlanamamıştır. Mevcuttaki yapay aydınlatma tasarımı atölyelerin genelinde istenilen aydınlık düzeyini sağlamasına karşın homojen bir aydınlık düzeyi elde etmek için yetersizdir. Ölçümlerdeki değerlendirmeler sonucunda düzgünlük değerinin daha düşük olması sebebi ile Atölye A daha riskli bulunmuştur. Atölyede aydınlık ortamını homojen hale getirmek ve enerji verimliliği sağlamak amacıyla minimum ve maksimum değerler belirlenmiştir. Bu doğrultuda iyileştirilmesi gereken bölgeler tespit edilmiş ve bölgelere uygun öneriler getirilmiştir.

DIALux Evo 8.2 programında Atölye A modellenmiş ve iki öneri sunulmuştur. Öneri 1 'de mevcut aydınlatma planı ve armatür türü, gücü değiştirilmeden daha yüksek lümene sahip dimmerli armatür kullanılmıştır. Bu öneride farklı bölgelerdeki aydınlık ihtiyacına göre aydınlık yüzdeleri belirlenmiştir. Mevcut durumdaki armatürle aynı güçte armatür kullanılmasına karşın bölgesel olarak ayarlanması aydınlatma gücü yoğunluğu(LPD) değerini düşürmüş ve enerji tüketimini \%20 ile \%53 arasında azaltmıştır. Bunun yanı sıra duvar kenarında bulunan köşeler istenilen aydınlık düzeyine getirilememiş fakat mevcut duruma göre daha homojen aydınlık düzeyine ulaşılmıştır. Genel atölye durumuna bakıldığı zaman görsel konfor koşullarında ve enerji tüketiminde iyileştirme sağlanmıştır.

Öneri 2'de mevcuttaki armatüre göre etkinlik faktörü $(\mathrm{Im} / \mathrm{w})$ daha yüksek olan LED armatür kullanıımıştır. Bu öneride farklı bölgelerdeki aydınlık intiyacına göre armatürler için anahtar planı önerilmiştir. Aynı zamanda daha düşük güce sahip armatür kullanıması aydınlık güç yoğunluğu (LPD) değerini düşürmüş ve enerji tüketimini \%57 ile \%63 arasında azaltmıştır. Bununla birlikte mevcut duruma göre daha homojen aydınlık düzeyine sahip bir atölye ortamı elde edilmiştir.

Yapılan simülasyonlarla önerilerin mevcut duruma göre daha homojen ve istenilen bir aydınlık düzeyi sağladığı görülmüştür. Aynı zamanda enerji tüketiminde de iyileştirme sağlanmıştır. Öneriler karşılaştırıldığında ise Öneri 2'de hem daha yüksek oranda enerji verimliliği sağlanmış hem de daha düzgün aydınlık düzeyi elde edilmiştir. Bu sebeple Atölye A'da optimum görsel konfor koşulları ve enerji verimliliği için en uygun görülen durum Öneri 2'dir.

DIALux Evo programında incelenen öneriler sonucunda bir mekânda tasarlanacak olan aydınlatma planının bölgesel olarak düşünülmesi, anahtar planının bu doğrultuda düzenlenmesi ve uygun armatür türünün seçilmesi görsel konfor ve enerji tasarrufu açısından optimum koşullar sunacaktır. Bu çalışmanın konfor koşulları dikkate alınarak enerji iyileştirmesi sağlayacak diğer çalışmalara katkı sağlaması hedeflenmiştir. 


\section{TEŞEKKÜRLER}

Kocaeli Üniversitesi Mimarlık ve Tasarım Fakültesi Mimarlık Anabilim Dalı Yüksek Lisans programında, "Mimarlıkta Enerji Etkin Tasarım" dersi kapsamında yürütülen çaış̧mada bilimsel katkılarından dolayı Doç. Dr. Neslihan Türkmenoğlu Bayraktar'a teşekkür ederiz.

\section{KAYNAKLAR}

Bircan, Pınar, Köknel Yener, Alpin, İlköğretim Dersliklerinde Günışığı Performansının Ts En 17037 Standardı Açısından Değerlendirilmesine İlişkin Bir Çalışma, 12. Ulusal Aydınlatma Kongresi Bildiriler Kitabı / Ed. Esra Küçükkılıç Özcan, M. Berker Yurtseven, Emre Erkin, İstanbul: Aydınlatma Türk Milli Komitesi, 2019, s.94-104

Cao, Guanying Sun, Yue, Liu, Xin, Qu, Wenjie, Zou, Nianyu "Analysis of Daylight Glare aand Optimal Lighting Design for Comfortable Office Lighting", Optik, 2020

Çelik, Kasım, Ünver, F. Rengin, "Eğitim Yapılarında Sürdürülebilir Aydınlatma Tasarımı Yaklaşımı", Çukurova Üniversitesi Mühendislik Mimarlık Fakültesi Dergisi, 34(3), Eylül 2019

Erlalelitepe, İlknur, Aral, Duygu, Kazanasmaz, Tuğçe, "Eğitim Yapılarının Doğal Aydınlatma Performansı Açısından İncelenmesi", Megaron 2011;6(1): 39-51

Heschong, Lisa, Wright, Roger L., Okura, Roger L., "Daylighting Impacts on Human Performance in School", Journal of the Illuminating Engineering Society, 2002, 31:2, s. 101-114

Nabil, A., \& Mardaljevic, J., "Useful daylight illuminance: a new paradigm for assessing daylight in buildings", Lighting Research \& Technology, 2005, 37(1), 41-57.

Memiş, Özge, Ekren, Nazmi, "Insan Odaklı Aydınlatma", Int. Per. of Recent Tech. in App. Eng., 2019, 1: s. 30-35

Michael, Aimilios, Heracleous, Chryso, "Assessment of natural lighting performance and visual comfort of educational architecture in Southern Europe: The case of typical educational school premises in Cyprus" Energy and Buildings, 2016, 140, 443-457

Salata, Ferdinando, Golasi, lacopo, di Salvatore, Maicol, de Lieto Vollaro, Andrea, "Energy and reliability optimization of a system that combines daylighting and artificial sources. A case study carried out in academic buildings. Applied Energy, 2016, 169, s. 250-266.

Sümengen, Özlem, Köknel Yener, Alpin, "Konutlarda Aydınlatma Enerjisi Performansı ve Görsel Konfor Koşulları", TMMOB VII. Ulusal Aydınlatma Sempozyumu ve Sergisi, Türkiye, 2015

Topçu, Sema, "Açık Ve Bulutlu Atmosfer Koşullarında Saatlik Toplam Işınım Öngörüsü İçin Bir Model", Doktora Tezi, İstanbul Teknik Üniversitesi, Fen Bilimleri Enstitüsü, 1988 , s.32 
Yağmur, Aydın, Şensin, Sözen, Şerefhanoğlu, Müjgan, "Dersliklerde Görsel Konfor ve İ̧ Yüzeylerin Etkisi”, Megaron 2016;11(1):49-62

Yıldız, Yusuf, "Dersliklerde Günışığı Performansının Değerlendirilmesi: Balıkesir Üniversitesi Örneği”, T.C. İstanbul Kültür Üniversitesi, 9. Ulusal Çatı \& Cephe Konferansı 12 - 13 Nisan 2018

URL 1. https://cevreselgostergeler.csb.gov.tr/sektorlere-gore-toplam-enerji-tuketimi-i85800 (Erişim: 4.12.2019)

URL 2. Kamu Binalarında Enerji Verimliliği Etüdü, Uygulama İzleme Raporo-1, 2018, bkz. http://www.yegm.gov.tr/ (Er: 30.11.2019)

URL 3. https://keos.izmit.bel.tr/keos/ (Er: 17.11.2019)

TS EN 12464-1:2013 